Illinois State University

ISU ReD: Research and eData

Theses and Dissertations

$10-29-2013$

\title{
Understanding Turnover Propensity Via Affective Beliefs
}

Adam Bradshaw

Illinois State University, bradshaw@degarmogroup.com

Follow this and additional works at: https://ir.library.illinoisstate.edu/etd

Part of the Quantitative Psychology Commons, and the Vocational Rehabilitation Counseling Commons

\section{Recommended Citation}

Bradshaw, Adam, "Understanding Turnover Propensity Via Affective Beliefs" (2013). Theses and Dissertations. 58.

https://ir.library.illinoisstate.edu/etd/58

This Thesis is brought to you for free and open access by ISU ReD: Research and eData. It has been accepted for inclusion in Theses and Dissertations by an authorized administrator of ISU ReD: Research and eData. For more information, please contact ISUReD@ilstu.edu. 


\title{
UNDERSTANDING TURNOVER PROPENSITY VIA AFFECTIVE BELIEFS
}

\author{
Adam L. Bradshaw
}

53 Pages

December 2013

Three latent variable models examined relationships among neuroticism, situationspecific affective beliefs, and turnover propensity and were evaluated with Structural Equation Modeling to determine model fit. Results provided additional insight into how affective belief systems relate to turnover propensity reinforcing and expanding upon previous research by Binning, Bradshaw, LeBreton, and Scheier (2010) as the Correlated Antecedents and the Mediated Antecedents Models fit the data as proposed. Neuroticism and situation-specific affective beliefs continue to play distinguishable roles in explaining turnover propensity. Research by Binning et al. (2010) and the present study make it increasingly clear that understanding how affective belief systems relate to turnover propensity increases our understanding of what employees have the proclivity to actually turnover. 
UNDERSTANDING TURNOVER PROPENSITY VIA AFFECTIVE BELIEFS

ADAM L. BRADSHAW

A Thesis Submitted in Partial Fulfillment of the Requirements for the Degree of

MASTER OF SCIENCE

Department of Psychology

ILLINOIS STATE UNIVERSITY 
(C) 2013 Adam L. Bradshaw 
UNDERSTANDING TURNOVER PROPENSITY VIA AFFECTIVE BELIEFS

ADAM L. BRADSHAW

COMMITTEE MEMBERS:

John F. Binning

Matthew Hesson-McInnis 


\section{ACKNOWLEDGEMENTS}

I would like to thank my committee members for their commitment to my learning experience throughout the thesis process. A special thank you to David Daly and Katy Melcher for their vested interest in ensuring I stay on task throughout the ups and downs of completing my thesis. Finally, the support provided by my family kept me on task and limited my doubts for success - thank you.

This thesis is dedicated to John F. Binning, PhD. and the DeGarmo Group staff for inspiring me to enter the world of Industrial Organizational Psychology and, most of all, to my loving wife, Ashley S. Bradshaw, MS, RD, LDN, for her continued support in all areas of work and life.

A.L.B. 


\section{CONTENTS}

Page

ACKNOWLEDGEMENTS

CONTENTS

TABLES

FIGURES

CHAPTER

i

ii

iv

V

Correlated Antecedents Model

Mediated Antecedents Model

Moderated Antecedents Model

Participants 15

$\begin{array}{ll}\text { Procedure } & 15\end{array}$

$\begin{array}{ll}\text { Measures } & 16\end{array}$

Situation-specific Affective Beliefs 16

Neuroticism 17

$\begin{array}{ll}\text { Outcomes Measures } & 19\end{array}$

IV. RESEARCH ANALYSES AND RESULTS 20

$\begin{array}{ll}\text { Structural Equation Modeling } & 22\end{array}$ 
Correlated Antecedents Model 23

Mediated Antecedents Model 28

Moderated Antecedents Model 33

Summary of Results $\quad 42$

V. DISCUSSION AND CONCLUSIONS 43

Implications for Practice $\quad 46$

Limitations $\quad 47$

Directions for Future Research 48

Concluding Remarks 49

$\begin{array}{lr}\text { REFERENCES } & 50\end{array}$ 


\section{TABLES}

Table

Page

1. Situation-specific Affective Beliefs: Factors, Dimensions, Items and Coefficient Alphas

2. Neuroticism: Factor, Facets, Items and Coefficient Alpha

3. Means, Standard Deviation, Alpha, and Correlation Coefficients for Indicators

4. Comparative Fit Indices for the Correlated Antecedents Model

5. Correlated Antecedents Model: Unstandardized Coefficients, Standard Errors, $\mathrm{t}$-values, and $\mathrm{R}^{2}$ for Latent Variables

6. Correlated Antecedents Model: Theta-Delta \& Theta-Epsilon

7. Comparative Fit Indices for the Mediated Antecedents Model

8. Mediated Antecedents Model: Unstandardized Coefficients, Standard Errors, t-values, and $\mathrm{R}^{2}$ for Latent Variables

9. Mediated Antecedents Model: Theta-Delta \& Theta-Epsilon

10. Orthogonalized Indicator Products

11. Comparative Fit Indices for the Moderated Antecedents Model

12. Moderated Antecedents Model: Unstandardized Coefficients, Standard Errors, t-values, and $\mathrm{R}^{2}$ for Latent Variables

13. Moderated Antecedents Model: Theta-Delta \& Theta-Epsilon of Main Effect Latent Variables Only

14. Moderated Antecedents Model: Theta-Deltas for Interaction Latent Variable Only

15. Moderated Antecedents Model: Theta-Delta \& Theta-Epsilon Interaction Latent Variable Only 


\section{FIGURES}

Figure $\quad$ Page

1. Causal Model Characterizing the Turnover Process 1

2. The Correlated Antecedents Model 9

3. The Mediated Antecedents Model 11

4. The Moderated Antecedents Model 13

5. Correlated Antecedents Model Results 25

6. Mediated Antecedents Model Results 30

7. Moderated Antecedents Model Results 37

8. Rough Causal Order of Turnover Related Criterion 45 


\section{CHAPTER I}

\section{INTRODUCTION}

Employee turnover is a perennial problem in the workplace because of its disruptive and costly effects. Turnover costs can be significant due to factors such as Human Resource (HR) administrative demands, production losses, potential loss of customers, and hiring and training demands, to name a few (Cascio, 1991; Tziner \& Birati, 1996). Due to the costs and disruptions associated with voluntary turnover, there is considerable interest in identifying employees who have the propensity to turnover prior to their employment (Adorno \& Binning, 2001; Binning, Bradshaw, LeBreton, \& Scheier, 2010; LeBreton, Binning, Adorno, \& Melcher, 2004; Ringler, Binning \& Schneider, 2001; Zimmerman, 2008). Generally speaking, situational demands create opportunities for negative affective reactions and employees who experience more frequent and intense negative affect at work are more likely to turnover voluntarily (Holtom, Mitchell, Lee, \& Interrieden, 2005; LeBreton, et al., 2004; Morrell, Loan-Clarke, \& Wilkinson, 2004; Lee \& Mitchell, 1994). A simple causal model characterizing this process can be found in Figure 1.

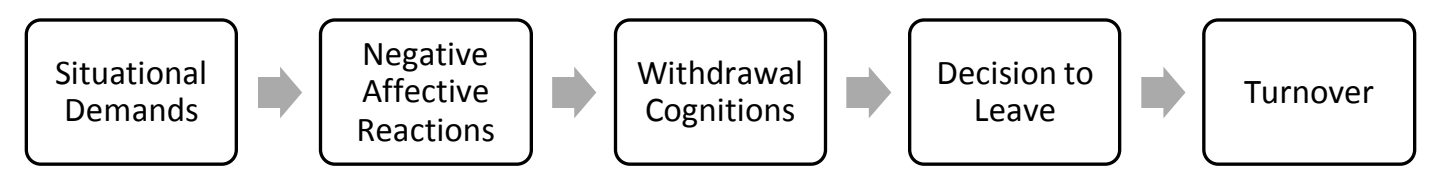

Figure 1. Causal Model Characterizing the Turnover Process. 
Applied HR staffing and selection specialists can leverage this causal sequence to identify those prospective employees who are more likely to react negatively to work demands, and thus screen them out prior to their employment to lower voluntary turnover. In the model proposed above, two general affective processes can be delineated. First, it is well known that individuals differ with regard to their general negative affectivity (e.g., trait neuroticism). Individuals who are higher in trait neuroticism experience more frequent and intense negative emotions across a wide spectrum of life situations. In addition to general negative affective predispositions, there is increasing evidence that individuals differ with regard to the types of specific situations that evoke negative affective reactions. In other words, two individuals may be equal in trait neuroticism (e.g., each score in the $78^{\text {th }}$ percentile for a normative sample on a standardized personality inventory), but one individual may react much more negatively to being criticized, whereas the other is strongly affected by standardization of work procedures. It is increasingly clear that general and situational-specific sources of negative affectivity combine to fuel turnover propensity (i.e., the proclivity of an employee to voluntary turnover), and I explored three latent structural equation models in an attempt to delineate this relationship in greater detail within the present study. 


\section{CHAPTER II}

\section{LITERATURE REVIEW}

\section{Understanding the Affective Causes of Voluntary Employee Turnover}

Researchers have consistently discussed voluntary turnover to be multiply determined by a variety of external (e.g., low pay, unsafe work environment), internal (e.g., high trait neuroticism), and interactive (e.g., idiosyncratic reactions to work environments) causes (Holtom, et al., 2005; Lee \& Mitchell, 1994; Morrell et al., 2004). External causes are not relevant to the discussion here, whereas identifying internal and interactive causes has utility within preemployment decision making contexts. Internal causes include an individual's personality (e.g., neuroticism) that can increase the likelihood to experience negative affect across work situations, as some individuals are prone to experiencing negative affect in general. Similarly, interactive causes include interactions with job-specific situations that can create the potential for negative affective reactions that often result from poor affective fit - the experience of frequent and intense negative affect. In turn, poor affective fit leads to negative beliefs associated with specific situations and situations in general (cf. Binning \& Bradshaw, 2012; Binning, et al., 2010). Individuals become sensitized to situations that engender negative affective reactions and develop affective beliefs of these situations. Accessing an individual's affective beliefs associated with situations in general, or in reaction to specific work-related situations, aids in our understanding of who has a greater likelihood to turnover (Binning et al., 2010). 


\section{Identifying Affective Beliefs to Predict Turnover Propensity}

Affective beliefs are beliefs based on memories about past experiences of negative affect, and different jobs pose different situations that resemble, more or less, of these past experiences (Binning et. al., 2010). Pre-employment contexts can tap into personal beliefs tied to job-relevant experiences to predict the likelihood of on-the-job affective reactions (LeBreton et al., 2004), and self-reports remain one of the best methods for assessing affective functioning in organizational settings (Brief \& Weiss, 2002). Robinson and Clore (2002) articulated some important distinctions regarding affective assessments. A fundamental issue regarding affective assessments is that individuals are capable of reporting about various aspects of their affective experiences, and instructional contexts play an important role in determining what is actually reported. Robinson and Clore proposed that when individuals report on affect, they can access at least four types of knowledge. They can access (a) their affect directly, (b) specific past events and the affect associated with them, (c) their beliefs about affect that specific situations might elicit, and (d) beliefs about their affect in general. These four informational bases are referred to as experiential knowledge, episodic memory, situation-specific affective beliefs, and identity-related affective beliefs, respectively.

One implication for self-report methodologies is that different memory systems underlie these sources, and therefore different aspects of affective functioning are accessible. The first two sources (experiential knowledge and episodic memory) are based on recall of specific events and episodes, whereas the latter two sources (situation-specific affective beliefs and identity-related beliefs) are based on semantic memory. Semantic memory is based on generalizations that develop over time and are resistant to updating. Episodic memory processes underlie self-reports of online emotional reactions as well as retrospective reports of specific recent events (Robinson $\&$ Clore, 2002). These are important information bases for studying affect in ongoing 
organizational settings (e.g., Grandey, 2000; Weiss \& Cropanzano, 1996). On the other hand, the utility of affective functioning for applied decision making (i.e., predicting job-candidates' affective-based future outcomes) often requires assessment of general affective tendencies and thus reliance on semantic memory-based reports of retrospective and prospective beliefs about future affective functioning (Binning et al., 2010).

One method to assess general affective tendencies is consistent with self-reports of identity-based beliefs (i.e., individual beliefs about their affect in general), which include selfreports of affectively-laden personality traits, including neuroticism. Neuroticism is the extent to which one is calm, confident, and steady versus tense, self-critical, and moody, and researchers have consistently characterized neuroticism as an affectively saturated personality construct within the Big Five taxonomy (Watson, Clark, \& Harkness, 1994; Watson, Wiese, Vaidya, \& Tellegen, 1999; Zuckerman, Kuhlman, Joireman, \& Teta, 1993). Measures of neuroticism are strongly correlated with trait negative affectivity (Ringler, Binning, \& Schneider, 2007; Watson \& Clark, 1992), and individuals higher in neuroticism and trait negative affect tend to experience negative emotions more often than those lower in these traits (Clark \& Watson, 1999, Watson, \& Clark, 1997, 1992). There are numerous studies that have explored neuroticism in work related contexts (e.g., Barrick \& Zimmerman, 2005; Binning et al., 2010; Connolly \& Viswesvaran, 2000; Judge \& Larsen, 2001; LeBreton, et al., 2004; Ringler, Binning, \& Schneider, 2007; Zimmerman, 2008), and neuroticism clearly plays a role in predicting and understanding turnover (Binning et al., 2010; LeBreton et al., 2004; Zimmerman, 2008).

A meta-analysis including 86 empirical studies conducted by Zimmerman (2008) found meta-analytic estimates of true-score correlations between neuroticism and intent to quit and neuroticism and turnover, such that neuroticism is significantly related to turnover intentions and behaviors. Furthermore, Zimmerman (2008) conducted a path analysis using meta-analytic 
correlation estimates demonstrating that neuroticism had direct effects with two proximal outcomes of turnover, including job satisfaction and intent to quit, and predicted turnover directly. Research by LeBreton et al. (2004) also found that neuroticism has significant predictive relationships to proximal outcomes of actual turnover, including attitudinal (i.e., job dissatisfaction), cognitive (i.e., negative job thoughts), and behavioral (i.e., negative job behaviors and absenteeism) outcomes. More specifically, relative importance analyses demonstrated that neuroticism was the most important predictor of job dissatisfaction, negative job thoughts, and negative job behaviors.

Similarly, reports of job-specific beliefs (e.g., job frustration sensitivity) are also consistent with assessment of general affective tendencies. As previously mentioned, poor affective fit can lead to negative affective beliefs in reaction to job-specific work-related situations (cf. Binning \& Bradshaw, 2012); and self-reports can capture these situation-specific affective beliefs. Situation-specific affective beliefs include an individual's beliefs or cognitions regarding a basic theory about how specific situations will create opportunities for certain affective reactions (Binning et al., 2010; Robinson \& Clore, 2002).

Binning et al. (2010) explored the role of situation-specific affective beliefs to aid in the prediction of turnover propensity. An interpretable factor structure of situation-specific affective beliefs was identified, including a three factor solution of High Pressure Situations, Routine Work Procedures, and Sales Demands \& Work Contexts. In turn, factors had meaningful intercorrelations with neuroticism and predicted turnover propensity, and neuroticism was a significant predictor of situation-specific affective beliefs. Binning et al. conducted hierarchical regression analyses demonstrating that the factors explained significant incremental variance for job satisfaction, negative job thoughts, and withdrawal behaviors beyond neuroticism alone. Understanding the significance the relationships between situation-specific affective beliefs and 
neuroticism in predicting and understanding the relationship to turnover propensity (i.e., the proclivity of an individual to turnover) warrants further investigation and will be elaborated below.

\section{Present Study}

Binning et al. (2010) established the basis for understanding the relation of situation-specific affective beliefs and neuroticism in predicting and understanding turnover propensity, but did not go so far as to explore the mechanism of how these constructs are related. Although it is clear that neuroticism and situation-specific affective beliefs have a role in predicting turnover propensity, it is not clear to what degree they do so, if there is an interactive process to predict turnover propensity, or if one moderates the other to explain the relationship to turnover propensity. It was my goal to delineate this relationship in greater detail within the present study through three structural models as outlined below.

Correlated Antecedents Model. Research by Binning et al. (2010) provided an initial attempt to evaluate how situation-specific affective beliefs covary with neuroticism. Binning et al. (2010) highlighted a meaningful and interpretable relationship between situation-specific affective beliefs and neuroticism. Within the Correlated Antecedents Model (Figure 2 below) I explored the hypothesized model to identify the covariance of situation-specific affective beliefs and neuroticism in an attempt to replicate this relationship. Furthermore, I examined the Correlated Antecedents Model to identify the direct effects of situation-specific affective beliefs and neuroticism on turnover propensity to establish their role in explaining turnover, as it is increasingly clear that affect plays an important role in determining the causes of voluntary turnover (LeBreton et al., 2004; Morrell et al., 2004; Zimmerman, 2008). Binning et al. (2010) found that neuroticism explained a significant percent of variance for negative job thoughts and withdrawal behaviors and that situation-specific affective beliefs explained significant 
incremental variance for job satisfaction, negative job thoughts, and withdrawal behaviors. These findings generally replicate the distinguishable roles that neuroticism and situation-specific affective beliefs play in explaining turnover propensity but warrant further investigation.

In sum, within the Correlated Antecedents Model, I hypothesized that the situation specific affective beliefs and neuroticism will have a direct effect on turnover propensity. Additionally, the covariance between situation-specific affective beliefs and neuroticism was examined. Using Structural Equation Modeling (SEM), I explored the proposed relations to expand on findings from Binning et al. (2010) to replicate and understand better the role of situation-specific affective beliefs and neuroticism in predicting turnover propensity.

Research Question 1: Does the proposed Correlated Antecedents Model fit the data as theorized in Figure 2 below? 


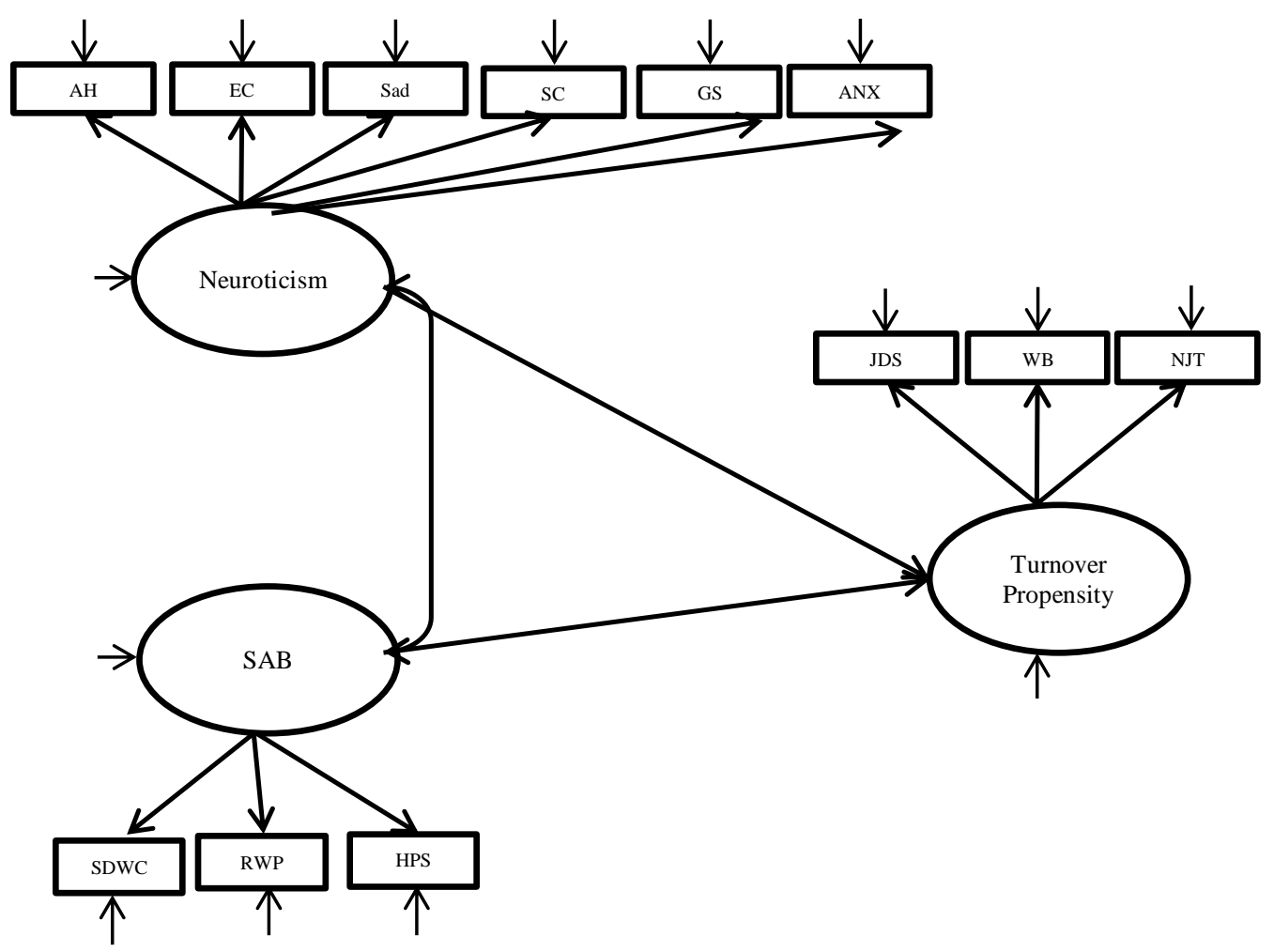

Note. The indicators for Neuroticism represent facets of Neuroticism, including Angry Hostility (AH), Emotional Control (EC), Sadness (SAD), Somatic Complaints (SC), Guilt/Shame (GS), and Anxiety (ANX). SAB represents Situation-specific Affective Beliefs and the indicators represent factors found by Binning et al. (2010), including Sales Demand and Work Contexts (SDWC), Routine Work Procedures (RWP), and High Pressure Situations (HPS). The three indicators for Turnover Propensity represent proximal outcomes to actual turnover, including Job Dissatisfaction (JDS), Withdrawal Behaviors (WB), and Negative Job Thoughts (NJT).

Figure 2. The Correlated Antecedents Model.

Mediated Antecedents Model. The Mediated Antecedents Model (Figure 3 below) explored situation-specific affective beliefs as a mediator of neuroticism to predict turnover propensity as situation-specific affective beliefs may account better for (i.e., mediate) the relationship between neuroticism and turnover propensity. The Correlated Antecedents Model might not account for the data sufficiently due to a directional effect of neuroticism on situationspecific affective beliefs, thus I hypothesized that neuroticism will have a direct effect on situation-specific affective beliefs as consistent with Binning et al. (2010) who demonstrated a 
significant, predictive relationship of neuroticism on situation-specific affective beliefs. I also hypothesized that neuroticism will have an indirect effect on turnover propensity as mediated by situation-specific affective beliefs. To my knowledge, no research has explored the role of situation-specific affective beliefs as a mediator of neuroticism. Finally, situation-specific affective beliefs will have a direct effect on turnover propensity. Binning et al. (2010) demonstrated predictive relationships of situation-specific affective beliefs on turnover propensity. Consistent with the Correlated Antecedents Model, I used SEM to explore the proposed relationships to expand on findings from Binning et al. (2010) to explore further the role of situation-specific affective beliefs and neuroticism in predicting turnover propensity via mediation. To my knowledge, no research has focused on examining situation-specific affective beliefs as a mediator of neuroticism to predict turnover propensity using SEM.

Research Question 2: Does the proposed Mediated Antecedents Model fit the data as theorized in Figure 3 below? 


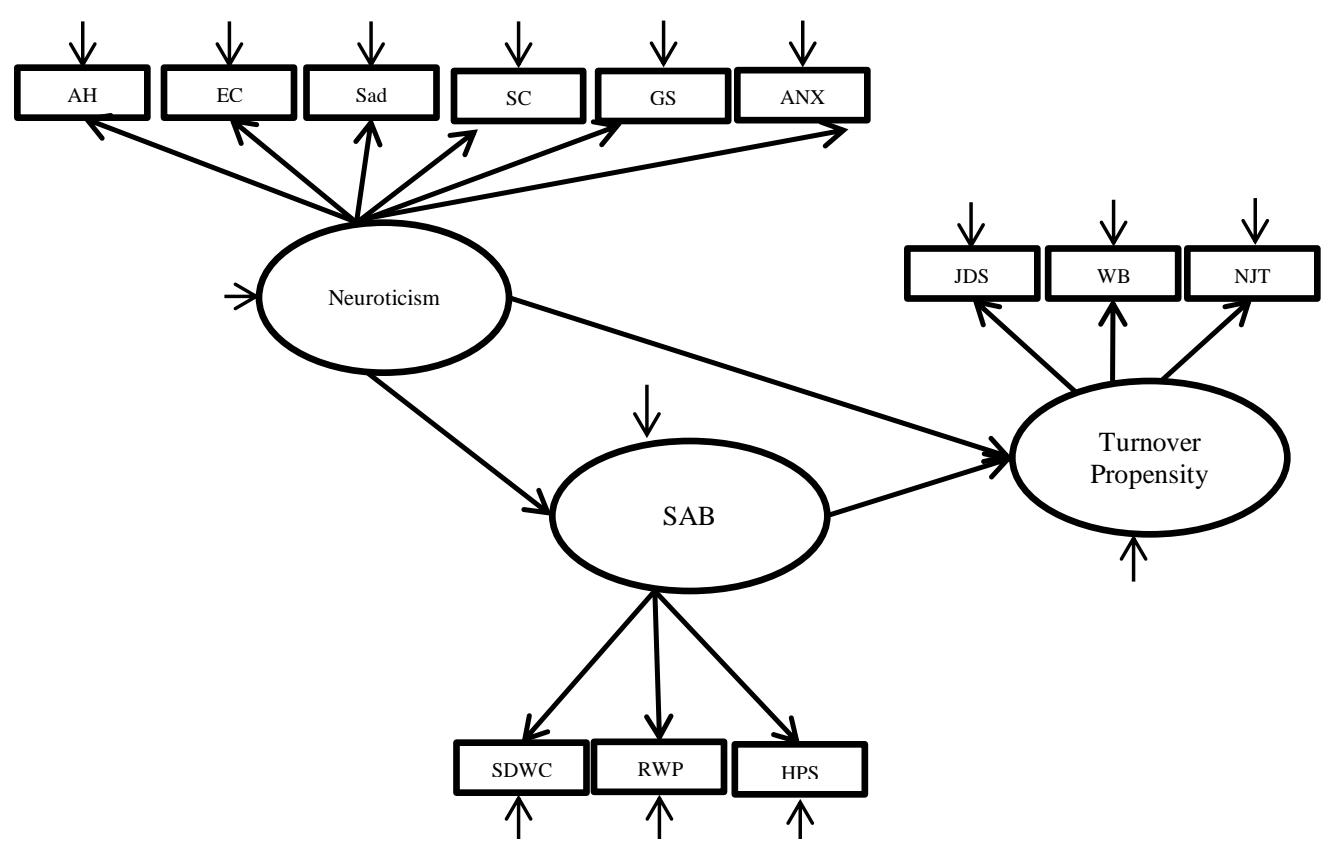

Note. The indicators for Neuroticism represent facets of Neuroticism, including Angry Hostility (AH), Emotional Control (EC), Sadness (SAD), Somatic Complaints (SC), Guilt/Shame (GS), and Anxiety (ANX). SAB represents Situation-specific Affective Beliefs and the indicators represent factors found by Binning et al. (2010), including Sales Demand and Work Contexts (SDWC), Routine Work Procedures (RWP), and High Pressure Situations (HPS). The three indicators for Turnover Propensity represent proximal outcomes to actual turnover, including Job Dissatisfaction (JDS), Withdrawal Behaviors (WB), and Negative Job Thoughts (NJT).

Figure 3. The Mediated Antecedents Model.

Clearly, neuroticism may have an indirect effect through situation-specific affective beliefs on turnover propensity to account better for (i.e., mediate) the relationship between neuroticism and turnover propensity. On the other hand, as noted by LeBreton et al. (2004) many, if not all, work-related contexts create demands for displaying particular behaviors despite certain job-specific demands that may create negative affective reactions (e.g., irate customers or a stressful work load); therefore employees may have to monitor and control how they display affective reactions (e.g., suppressing the urge to yell or scowl at an irate customer), creating opportunities for negative reactions to work demands. This notion is consistent with a person $\mathrm{X}$ situation interaction perspective (Binning et al., 2010; Tett, \& Burnett, 2003; Tinsley, 2000), such that job-specific affect (i.e., situation-specific beliefs) may emerge as an important construct in 
understanding the direction and strength of (i.e., moderate) the relation between neuroticism and turnover propensity.

Moderated Antecedents Model. The Moderated Antecedents Model (Figure 4 below) explored situation-specific affective beliefs as a moderator of neuroticism to predict turnover propensity. I hypothesized that situation-specific affective beliefs and neuroticism will have direct effects on turnover propensity as consistent with the Correlated Antecedents Model, but the Moderated Antecedents Model also posits a moderated relationship between neuroticism and situation-specific affective beliefs. Therefore, the interaction between neuroticism and situationspecific affective beliefs was examined to identify if situation-specific affective beliefs play a role in influencing the strength of the relationship between neuroticism and turnover propensity. Consistent with the Correlated Antecedents Model and the Mediated Antecedents Model, I used SEM to explore the proposed relationships to expand on findings from Binning et al. (2010) to understand better the role of situation-specific affective beliefs and neuroticism in predicting turnover propensity via moderation. To my knowledge, no research has focused on examining situation-specific affective beliefs as a moderator of neuroticism to predict turnover propensity using SEM.

Research Question 3: Does the proposed Moderated Antecedents Model fit the data as theorized in Figure 4 below? 


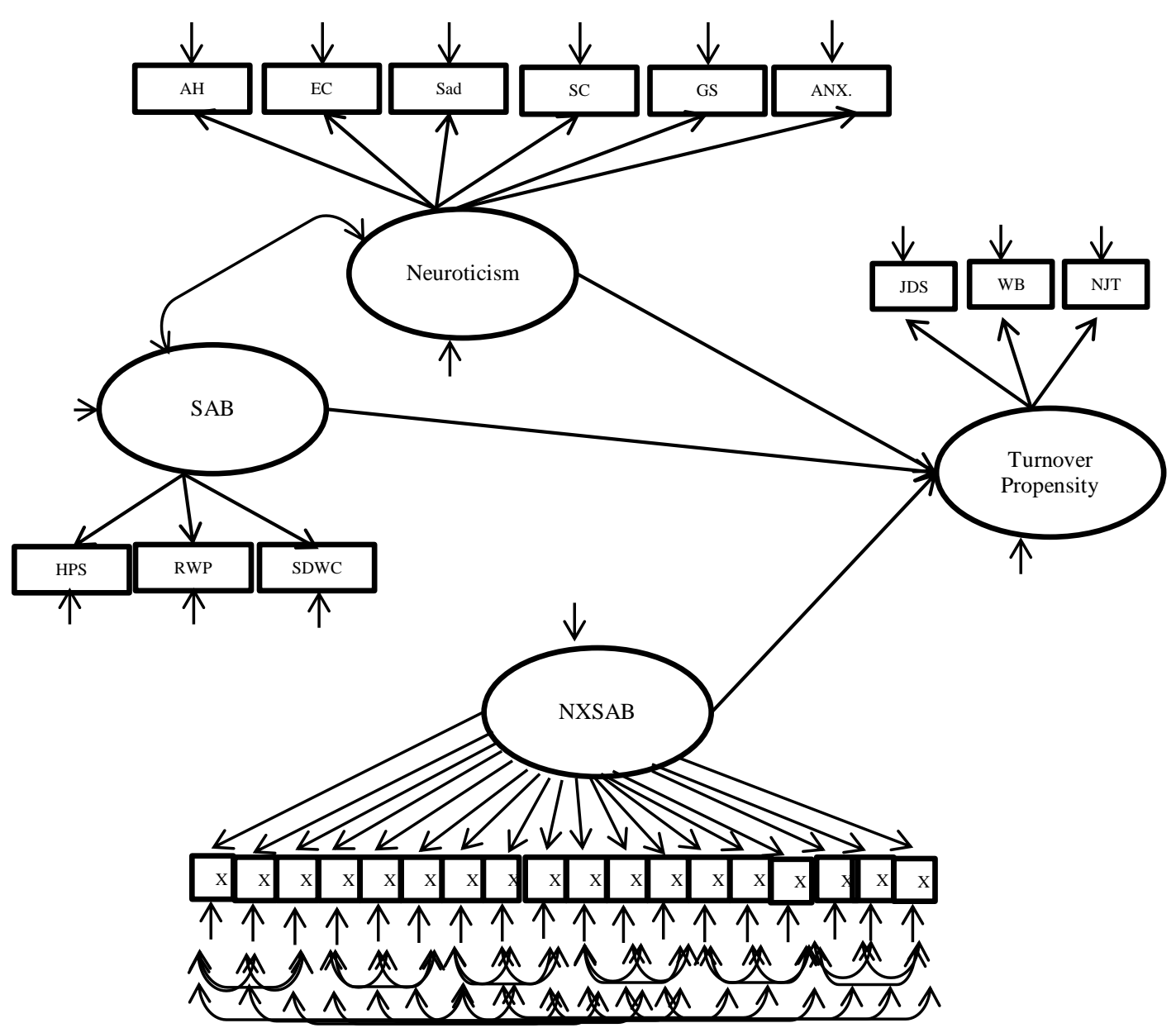

Note. The indicators for Neuroticism represent facets of Neuroticism, including Angry Hostility (AH), Emotional Control (EC), Sadness (SAD), Somatic Complaints (SC), Guilt/Shame (GS), and Anxiety (ANX.). SAB represents Situation-specific Affective Beliefs and the indicators represent factors found by Binning et al. (2010), including Sales Demand and Work Contexts (SDWC), Routine Work Procedures (RWP), and High Pressure Situations (HPS). The three indicators for Turnover Propensity represent proximal outcomes to actual turnover, including Job Dissatisfaction (JDS), Withdrawal Behaviors (WB), and Negative Job Thoughts (NJT). NXSAB represents the interaction of neuroticism and situation-specific affective beliefs. Consistent with Little et al., (2006), Figure 4 includes two important features. First, each of the 18 indicators has unique variance common with other indicators depending on which of the first-order effect indicators was used to create it. Thus, correlations between the residual variances of the interaction indicators must be specified accordingly. Second, the latent interaction term is not correlated with the main effect variables as the indicators of the interaction term have been orthogonalized creating covariances of zero for the relations between the main effect indicators and the interaction indicators.

Figure 4. The Moderated Antecedents Model. 
In sum, I hypothesized three structural models in the present study (Figures 2-4 above) in an attempt to facilitate better our understanding of how situation-specific affective beliefs and neuroticism account for variance in turnover propensity via SEM. Structural Equation Modeling provides the opportunity to examine the relative and absolute fit of each of the three models. The latent variable Situation-specific Affective Beliefs represents individual beliefs or cognitions about how specific situations will create opportunities for certain affective reactions. Subscales were computed for each of the three factors of situation-specific beliefs determined by Binning et al, 2010, including Sales Demands \& Work Contexts, Routine Work Procedures, and High Pressure Situations and used to represent the indicators of Situation-specific Affective Beliefs. The latent variable Neuroticism represents the extent to which one is calm, confident, and steady versus tense, self-critical, moody. The six facets of Neuroticism, including Angry Hostility, Emotional Control, Sadness, Somatic Complaints, Guilt/Shame, and Anxiety represent indicators of Neuroticism. The latent variable Turnover Propensity represents the proclivity of an employee to voluntarily turnover, and the subscales Job Dissatisfaction, Withdrawal Behaviors, and Negative Job Thoughts are indicators that represent proximal outcomes of actual turnover, including attitudinal (i.e., job dissatisfaction), cognitive (i.e., negative job thoughts), and behavioral (i.e., negative job behaviors and absenteeism) outcomes (LeBreton et al., 2004). Note that the Moderated Antecedents Model will also include an additional, latent variable representing the interaction of Neuroticism and Situation-specific Affective Beliefs. The indicators of Neuroticism X Situation-specific Affective Beliefs include the interaction of the six indicators for Neuroticism and the three indicators for Situation-specific Affective Beliefs for a total of 18 indicators. 


\section{CHAPTER III}

\section{RESEARCH DESIGN AND METHODOLOGY}

\section{Participants}

The data used for analysis was archival and provided only minimal demographic information to maintain strict confidentiality regarding participant information. Participants consisted of incumbents from retail sales positions, including a total of 247 full-time retail sales representatives employed by a wireless telecommunications company. Of the 247 participants, $102(41.3 \%)$ were female; $123(49.8 \%)$ were male; and $22(8.9 \%)$ declined to indicate their gender. Additionally, the sample included 11 (4.5\%) African-American participants, $3(1.2 \%)$ American Indian participants, 1 (0.4\%) Asian participants, 201 (81.4\%) European American participants, 5 (2.0\%) Hispanic participants, 1 (0.4\%) Pacific Islander participants, 10 (4.0\%) other participants; and $15(6.1 \%)$ of the participants left the response blank. Data were used with permission from a Human Resource Consulting firm.

\section{Procedure}

Data were collected via web-based surveys from the sample of incumbent retail sales representatives. The survey contained the $\mathrm{RSFI}^{\circledR}$ and a separate page indexing job attitudes, withdrawal cognitions, and criterion behaviors. The $\mathrm{RSFI}^{\circledR}$ asks participants to respond to two sections as outlined and described below. 


\section{Measures}

Situation-specific Affective Beliefs. Section A of the RSFI ${ }^{\circledR}$ assesses situation-specific affective beliefs via job frustration sensitivity through forced-choice tetrads, where job-specific situations were constructed using job analysis and subject matter experts in a manner as described by LeBreton, Binning, Adorno, and Melcher (2004). Specifically, the assessment consists of 160 items, which were originally compiled and sorted according their degree of frustration and relevance to the job. Items were then organized into 40 tetrads according to their degree of frustration. Two items within each tetrad are job relevant, and two items are not job relevant. Instructions direct job applicants to choose two items from each tetrad that they would find most frustrating or bothersome if actually encountered on the job. Thus, if more job-relevant items are selected as frustrating, an applicant will purportedly experience more frustration once actually on the job. A sample item includes the following:

a. Being rejected by others.

b. Being evaluated according to closely monitored statistics.

c. Working with dissatisfied customers or clients.

d. Working under conditions that may be physically uncomfortable.

In this example, responses $b$ and $c$ represent the keyed, job related responses. Furthermore, items have been categorized across judgmentally constructed dimensions, such that similar items were grouped into similar dimensions (e.g., the dimension Using Electronic Equipment includes items like entering information in electronic form.). Results from Binning et al. (2010) determined the replicability of a three factor solution of situation-specific affective beliefs, such that dimension scores were normalized and then summed to yield subscale scores. Factor names, dimensions, sample items, and coefficient alphas can be found in Table 1 below. 
Table 1

Situation-specific Affective Beliefs: Factors, Dimensions, Items and Coefficient Alphas.

\begin{tabular}{|c|c|c|c|}
\hline$\underline{\text { Factor Name }}$ & $\underline{\text { Dimension }}$ & $\underline{\text { Sample Item }}$ & $\begin{array}{l}\text { Coefficient } \\
\text { Alpha* }\end{array}$ \\
\hline \multirow[t]{3}{*}{$\begin{array}{l}\text { High Pressure } \\
\text { Situations }\end{array}$} & $\begin{array}{l}\text { Negative Customer } \\
\text { Relations }\end{array}$ & Dealing with discourteous people. & $.63(.73)$ \\
\hline & $\begin{array}{l}\text { Working Under Time } \\
\text { Pressure }\end{array}$ & Making decisions quickly. & \\
\hline & $\begin{array}{l}\text { Emotionally Stressful } \\
\text { Situations }\end{array}$ & $\begin{array}{l}\text { Having to accept criticism without } \\
\text { getting upset. }\end{array}$ & \\
\hline \multirow[t]{3}{*}{$\begin{array}{l}\text { Routine Work } \\
\text { Procedures }\end{array}$} & $\begin{array}{l}\text { Using Electronic } \\
\text { Equipment } \\
\text { Processing } \\
\text { Transactions }\end{array}$ & $\begin{array}{l}\text { Reading information from a } \\
\text { computer screen. } \\
\text { Maintaining records related to } \\
\text { sales. }\end{array}$ & $.57(.56)$ \\
\hline & Attention to Detail & $\begin{array}{l}\text { Paying close attention to detailed } \\
\text { specifications. }\end{array}$ & \\
\hline & $\begin{array}{l}\text { Adhering to Policies } \\
\text { and Procedures }\end{array}$ & $\begin{array}{l}\text { Following established work } \\
\text { schedules and procedures. }\end{array}$ & \\
\hline \multirow{5}{*}{$\begin{array}{l}\text { Sales } \\
\text { Demands and } \\
\text { Work Context }\end{array}$} & $\begin{array}{l}\text { Performance } \\
\text { Management }\end{array}$ & Working on a commission basis. & $.62(.76)$ \\
\hline & Selling Process & $\begin{array}{l}\text { Demonstrating use or operation of } \\
\text { merchandise. }\end{array}$ & \\
\hline & Customer Service & $\begin{array}{l}\text { Providing assistance to clients or } \\
\text { customers throughout the work } \\
\text { day. }\end{array}$ & \\
\hline & Customer Relations & $\begin{array}{l}\text { Making people feel welcome and at } \\
\text { ease. }\end{array}$ & \\
\hline & $\begin{array}{l}\text { Irregular Work } \\
\text { Schedule }\end{array}$ & $\begin{array}{l}\text { Working different shifts each week } \\
\text { or month. }\end{array}$ & \\
\hline
\end{tabular}

*Reported coefficient alphas are from samples of 2,030 (and 247) by Binning et al. (2010).

Neuroticism. Section B of the $\mathrm{RSFI}^{\circledR}$, also referred to as the DeGarmo Personality Inventory (DPI), was constructed in a manner as described by LeBreton et al., (2004). The original item pool for all six traits was derived from items made available through the International Personality Item Pool. The original pool of items was reduced to the final set of 120 items after employing multiple techniques, including content analysis by subject matter experts, internal consistency analysis, exploratory factor analysis, and confirmatory factor analysis. 
Depending on the wording of items, participants respond to the items on a Likert scale from 1 (Never) to 7 (Always) or 1 (Strongly Disagree) to 7 (Strongly Agree). Section B measures several of the Big Five traits, including agreeableness (10 items), conscientiousness (22 items), emotional stability (i.e., neuroticism; 20 items), and extroversion (6 items). Reliability and validity information for the all traits listed can be found from LeBreton et al., (2004) and Binning et al., (2010), but the present study will focus solely on neuroticism and details will be provided below.

Neuroticism is characterized as the extent to which one is calm, confident, and steady versus tense, self-critical, and moody and includes 24 items. Factor and facet names, sample items, and relevant coefficient alphas can be found in Table 2 below.

Table 2

Neuroticism: Factor, Facets, Items and Coefficient Alpha.

\begin{tabular}{|c|c|c|c|}
\hline \multirow[t]{2}{*}{ Factor Name } & $\underline{\text { Facet }}$ & $\underline{\text { Sample Item }}$ & $\underline{\text { Coefficient }}$ \\
\hline & & & Alpha* \\
\hline \multirow[t]{8}{*}{ Neuroticism } & Angry Hostility & $\begin{array}{l}\text { I am known for easily getting } \\
\text { angry. }\end{array}$ & $.80(.82)$ \\
\hline & Emotional Control & $\begin{array}{l}\text { I may look calm, but inside I can } \\
\text { be very upset. }\end{array}$ & \\
\hline & Sadness & I break down and cry to release & \\
\hline & & tension. & \\
\hline & Somatic & I sweat a lot when I confront & \\
\hline & Complaints & others. & \\
\hline & Guilt/Shame & $\begin{array}{l}\text { I feel guilty about things I have } \\
\text { done. }\end{array}$ & \\
\hline & Anxiety & Sudden or loud noises startle me. & \\
\hline
\end{tabular}

*Reported coefficient alphas are from samples of 2,030 (and 247) by Binning et al. (2010).

Research by Binning et al. (2010) and LeBreton et al. (2004) demonstrates that neuroticism has significant predictive relationships to proximal outcomes of actual turnover including, attitudinal (i.e., job dissatisfaction), cognitive (i.e., negative job thoughts), and behavioral (i.e., negative job behaviors and absenteeism) outcomes. 


\section{Outcome Measures}

Consistent with Binning et al. (2010) I used outcome measures including Job

Dissatisfaction (a linear composite of 11 items; e.g., How satisfied are you in your current position $?-$ reverse scored item) with coefficient alpha $=.84$; Negative job thoughts (a linear composite of 9 items; e.g., I am proud to tell people what I do for a living - reverse scored item) with coefficient alpha $=.87$; and Withdrawal behaviors (a linear composite of 5 items; e.g., How many times have you missed a scheduled work shift for your current employer?) with coefficient alpha $=.58$. 


\section{CHAPTER IV}

\section{RESEARCH ANALYSES AND RESULTS}

Descriptive statistics and correlation coefficients are available within Table 3 below.

Correlations appear to be robust and in the expected direction. Moreover, there are numerous significant relationships at the $p<.05$ and $p<.01$ level. 
Table 3

Means, Standard Deviation, Alpha, and Correlation Coefficients for Indicators

\begin{tabular}{|c|c|c|c|c|c|c|c|c|c|c|c|c|c|c|c|}
\hline & $M$ & $S D$ & Alpha & $\mathrm{AH}$ & $\mathrm{EC}$ & $\mathrm{Sad}$ & SC & GS & ANX & SDWC & RWP & HPS & JDS & WB & NJT \\
\hline $\mathrm{AH}$ & 19.93 & 4,99 & .73 & -- & & & & & & & & & & & \\
\hline EC & 19.72 & 3.188 & .78 & $.57 * *$ & -- & & & & & & & & & & \\
\hline $\mathrm{Sad}$ & 22.55 & 4,36 & .81 & $.58^{* *}$ & $.57^{* *}$ & -- & & & & & & & & & \\
\hline SC & 22.22 & 3.79 & .68 & $.57 * *$ & $.52^{* *}$ & $.68^{* *}$ & -- & & & & & & & & \\
\hline GS & 21.21 & 3.93 & .73 & $.63^{* *}$ & $.56^{* *}$ & $.70^{* *}$ & $.66^{* *}$ & -- & & & & & & & \\
\hline ANX & 19.87 & 4.79 & .69 & $.62^{* *}$ & $.49^{* *}$ & $.63^{* *}$ & $.67^{* *}$ & $.70^{* *}$ & -- & & & & & & \\
\hline SDWC & .00 & 2.33 & .73 & .09 & $.15^{*}$ & $.14^{*}$ & .06 & .09 & .01 & -- & & & & & \\
\hline RWP & .00 & 2.42 & .56 & .09 & .05 & .04 & .03 & .01 & .04 & $.25^{* *}$ & -- & & & & \\
\hline HPS & .00 & 3.17 & .76 & $.19^{* *}$ & $.16^{*}$ & .12 & .12 & .09 & .04 & $.25^{* *}$ & .06 & -- & & & \\
\hline JDS & 3.59 & .70 & .84 & .10 & $.13^{*}$ & $.20^{* *}$ & .08 & .12 & .01 & $.19 * *$ & .04 & $.16^{*}$ & -- & & \\
\hline WB & 2.37 & .36 & .87 & $.23^{* *}$ & $.26^{* *}$ & $.26 * *$ & $.25^{* *}$ & $.15^{*}$ & $.15^{*}$ & $.25^{* *}$ & $.13^{*}$ & .02 & $.17 * *$ & -- & \\
\hline NJT & 2.64 & .46 & .58 & $.16^{* *}$ & $.26^{* *}$ & $.24 * *$ & $.15^{*}$ & .12 & .12 & $.33^{* *}$ & $.14^{*}$ & $.17 * *$ & $.51^{* *}$ & $.32 * *$ & -- \\
\hline
\end{tabular}

Note. $\mathrm{N}=247$. Correlations significant at the $\mathrm{p}<. .05$ are marked with an asterisk $(*)$. Correlations significant at the $\mathrm{p}<.01$ are marked with two asterisks $(* *)$. Abbreviated indicators include, Angry Hostility (AH), Emotional Control (EC), Sadness (SAD), Somatic Complaints (SC), Guilt/Shame (GS), and Anxiety (ANX), Sales Demand and Work Contexts (SDWC), Routine Work Procedures (RWP), and High Pressure Situations (HPS), Job Dissatisfaction (JDS), Withdrawal Behaviors (WB), and Negative Job Thoughts (NJT). 


\section{Structural Equation Modeling}

SEM was used to test the proposed models based on data from 247 retail sales representatives at a wireless telecommunications company. SEM is a powerful technique for assessing the fit of theoretical models to real data and for comparing the relative validity of models (Bollen, 1989). Using LISREL 8.80 Data Software (Joreskog \& Sorbom, 2006), SEM analysis was conducted to identify the degree to which the Correlated Antecedents, the Mediated Antecedents, and the Moderated Antecedents Model fits the data (Figures 2-4 above) as hypothesized a priori. Plans to bifurcate a larger data set as a way to create two stages of analysis including a model fitting and development stage and model testing and validation stage were unsuccessful as a large enough data set was not obtained. Thus, analyses were conducted with the $\mathrm{N}=247$ data set and examined for model fit.

Before analyses were conducted, identification status was evaluated. The Correlated Antecedents Model and the Mediated Antecedents Models are over-identified passing the t-rule (27 $\leq 78$ ), and they follow the Three Indicator Rule (Bollen, 1989). Furthermore, they have an appropriate ratio at the recommended levels 8 to 10 participants per estimated parameter (Nunnally, 1967). The Moderated Antecedents Model is also over-identified, passing the $t$ rule (i.e., $97 \leq 435$ ), and it follows the Three Indicator Rule (Bollen, 1989). There are 97 estimated parameters within the Moderated Antecedents Model and only 12 indicators, therefore the Moderated Antecedents Model did not meet the recommended guidelines for the requirement of a sufficient sample size as outlined above. The model had 97 parameters with a sample size of only 247, thus having about 3 participants to one model parameter. Therefore, as proposed, the Moderated Antecedents Model parameters were estimated and evaluated, but the results provide minimal room for interpretation, and concomitant limitations will be addressed below accordingly (Nunnally, 1967). 
Additionally, prior to SEM analysis, the sample was evaluated for missing data and outliers, such that no missing variables or outliers were removed retaining the initial sample of 247. Assumptions of multivariate normality and linearity were conducted and, for each variable, skewness and kurtosis were within reasonable values (i.e., two standard errors) to assume normality. If all variables are generally normally distributed, then multivariate normality is often assumed (Garson, 2009), and Maximum likelihood estimation (MLE) was used as the fitting function. Individual parameters were estimated and compared with the sample covariance matrix. Model Fit was examined and will be reported for each model below using numerous goodness-offit indicators, including the Non-Normed Fit Index (NNFI), the Comparative Fit Index (CFI), the root mean square error of approximation (RMSEA), and the Standardized Root Means Square Residual (SRMR), as recommended by Schreiber, Stage, Nora, and Barlow (2006). As outlined by Tanaka (1993), if the majority of the fit indices indicate good fit, there is probably good model fit to the data. Values $\geq .95$ indicated good fit for the NNFI, > .95 for the CFI, <.06 for the RMSEA, and $\leq .08$ for the SRMR (Schrieber, Stage, King, Nora, \& Barlow, 2006).

Correlated Antecedents Model. The Correlated Antecedents Model provided a good fit to the data as seen in Table 4. Post-hoc modifications were not conducted as the Correlated Model provided a good fit of the data to the model.

Table 4

Comparative Fit Indices for the Correlated Antecedents Model

\begin{tabular}{lccccccc}
\hline Model & $\chi^{2}$ & $d f$ & $P$ & RMSEA & SRMR & CFI & NNFI \\
\hline $\begin{array}{l}\text { Model 1 - } \\
\begin{array}{l}\text { Correlated } \\
\text { Antecedents }\end{array}\end{array}$ & 90.15 & 51 & $<.01$ & 0.05 & 0.06 & 0.98 & 0.97 \\
Model & & & & & & & \\
\hline $\begin{array}{l}\text { Note. } \text { p-values are only asymptotically correct under a stringent assumption of multivariate } \\
\text { normality and should largely be ignored. RMSEA = Root Mean Square Error of }\end{array}$ \\
$\begin{array}{l}\text { Approximation; SRMR = Standardized Root Mean Square Residual; CFI = Comparative Fit } \\
\text { Index; NNFI = Non-normed Fit Index; }\end{array}$
\end{tabular}


Results for the Correlated Antecedents Model can be found in Figure 5 and Tables 5 and 6 below. Interpreting the relationships discovered in Figure 5 should be undertaken with care as two out of three of the squared multiple correlations for the indicators of situation-specific affective beliefs do not exceed a commonly accepted cut-off of .32 (Tabachnick \& Fidell, 2007). The latent construct, situation-specific affective beliefs, explained only $8 \%$ percent $\left(R^{2}=0.08\right)$ of the variance in Routine Work Procedures, 18 percent $\left(R^{2}=0.18\right)$ in High Pressure Situations explained, whereas 79 percent $\left(R^{2}=0.79\right)$ of the variance in Sales Demands and Work Context was explained. The squared multiple correlations suggest that the three indicators proposed do not sufficiently adhere to explain the latent variable, situation-specific affective beliefs. It is noteworthy, however, that the $t$-values are all above 2 ranging from 3.68 for Routine Work Procedures to 7.23 for Sales Demand and Work Context. The same can be said for the latent construct, turnover propensity. Two out of the three squared multiple correlations for the indicators of turnover propensity do not exceed a commonly accepted cut-off of .32 (Tabachnick $\&$ Fidell, 2007). The latent construct, turnover propensity, explained 14 percent $\left(R^{2}=0.14\right)$ of the variance in Negative Job Thoughts, 32 percent $\left(R^{2}=0.32\right)$ of the variance in Withdrawal Behaviors, whereas 77 percent $\left(R^{2}=0.77\right)$ of the variance in Job Dissatisfaction was explained. Again, it is interesting to note that the $t$-values are all above 2 ranging from 5.36 for Negative Job Thoughts to 8.79 for Job Dissatisfaction.

Consistent with my hypotheses, Neuroticism $(\mathrm{B}=0.22, S E=0.08, t=2.68)$, and Situation-Specific Affective Beliefs $(\mathrm{B}=0.47, S E=0.12, t=3.96)$ predicted Turnover Propensity explaining 23 percent of the variance in Turnover Propensity $\left(\mathrm{R}^{2}=0.23\right)$. As previously noted, affect plays an important role in determining the causes of voluntary turnover (LeBreton et al., 2004; Morrell et al., 2004; Zimmerman, 2008) and the relationships found in the present study are consistent with work by Binning et al. (2010). Results generally support and replicate the 
distinguishable roles that neuroticism and situation-specific affective beliefs play in explaining turnover propensity as proposed. Finally, Neuroticism did not relate to Situation-specific Affective Beliefs as hypothesized ( $\mathrm{B}=0.14, S E=0.08, t=1.81)$. Binning et al. (2010) highlighted a meaningful and interpretable relationship between situation-specific affective beliefs and neuroticism. The minimal factor loadings for situation-specific affective beliefs may explain the lack of relationship between Neuroticism and Situation-specific Affective Beliefs as I originally hypothesized.

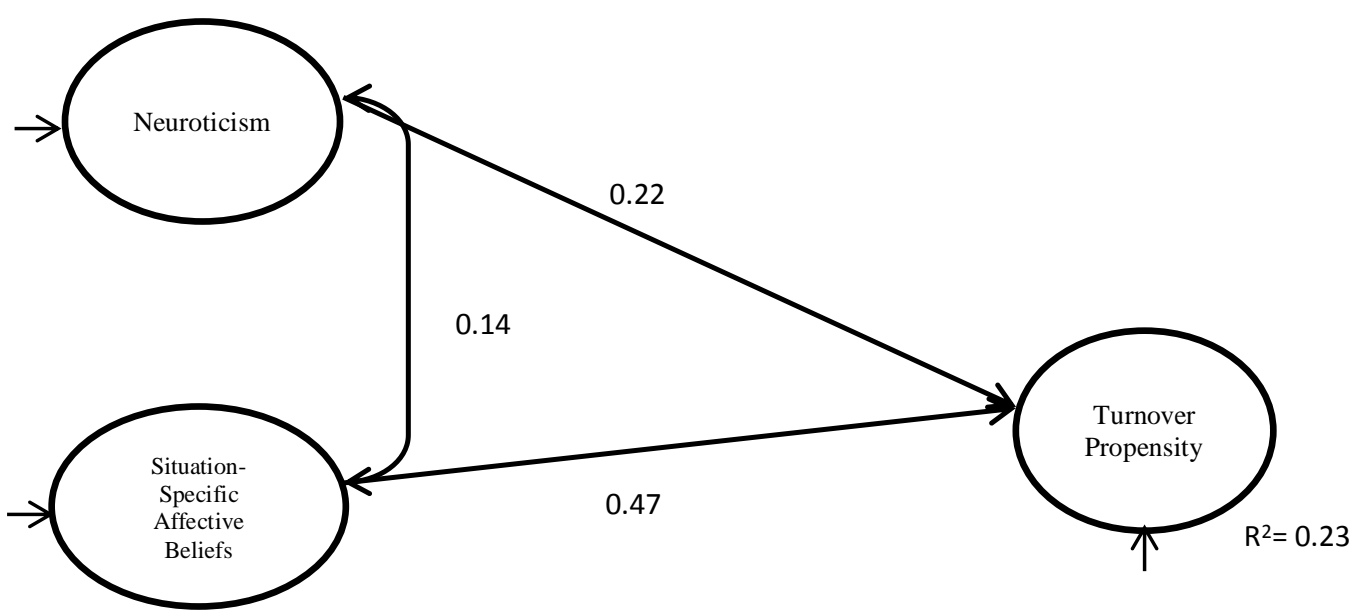

Figure 5. Correlated Antecedent Model Results. 
Table 5

Correlated Antecedents Model: Unstandardized Coefficients, Standard Errors, $t$-values, and $R^{2}$ for Latent Variables

\begin{tabular}{|c|c|c|c|c|c|}
\hline Observer Variable & Latent Variables & $\mathrm{B}$ & SE & $t$ & $\mathrm{R}^{2}$ \\
\hline Angry Hostility & Neuroticism & 3.71 & 0.28 & 13.21 & 0.55 \\
\hline Emotional Control & Neuroticism & 2.15 & 0.19 & 11.56 & 0.45 \\
\hline Sadness & Neuroticism & 3.56 & 0.23 & 15.16 & 0.67 \\
\hline Somatic Complaints & Neuroticism & 3.04 & 0.21 & 14.78 & 0.64 \\
\hline Guilt/Shame & Neuroticism & 3.32 & 0.21 & 16.00 & 0.71 \\
\hline Anxiety & Neuroticism & 3.85 & 0.26 & 14.77 & 0.64 \\
\hline $\begin{array}{c}\text { Sales Demand \& Work } \\
\text { Context }\end{array}$ & $\begin{array}{l}\text { Situation-Specific } \\
\text { Affective Beliefs }\end{array}$ & 2.81 & 0.39 & 7.23 & 0.79 \\
\hline $\begin{array}{l}\text { Routine Work } \\
\text { Procedures }\end{array}$ & $\begin{array}{l}\text { Situation-Specific } \\
\text { Affective Beliefs }\end{array}$ & 0.67 & 0.19 & 3.68 & 0.08 \\
\hline $\begin{array}{l}\text { High Pressure } \\
\text { Situations }\end{array}$ & $\begin{array}{l}\text { Situation-Specific } \\
\text { Affective Beliefs }\end{array}$ & 0.99 & 0.19 & 5.18 & 0.18 \\
\hline Job Dissatisfaction & $\begin{array}{l}\text { Turnover } \\
\text { Propensity }\end{array}$ & 0.35 & 0.04 & 8.79 & 0.77 \\
\hline Withdrawal Behaviors & $\begin{array}{l}\text { Turnover } \\
\text { Propensity }\end{array}$ & 0.35 & 0.04 & 7.84 & 0.32 \\
\hline Negative Job Thoughts & $\begin{array}{l}\text { Turnover } \\
\text { Propensity }\end{array}$ & 0.84 & 0.16 & 5.36 & 0.14 \\
\hline
\end{tabular}


Table 6

Correlated Antecedents Model: Theta-Delta \& Theta-Epsilon

\begin{tabular}{|c|c|c|c|c|}
\hline Observer Variable & Latent Construct & $\mathrm{B}$ & SE & $t$ \\
\hline $\begin{array}{l}\text { Angry Hostility } \\
\text { (theta-delta) }\end{array}$ & Neuroticism & 11.20 & 1.15 & 9.74 \\
\hline $\begin{array}{l}\text { Emotional Control } \\
\text { (theta-delta) }\end{array}$ & Neuroticism & 5.56 & 0.55 & 10.18 \\
\hline $\begin{array}{l}\text { Sadness } \\
\text { (theta-delta) }\end{array}$ & Neuroticism & 6.32 & 0.71 & 8.87 \\
\hline $\begin{array}{l}\text { Somatic Complaints } \\
\text { (theta-delta) }\end{array}$ & Neuroticism & 5.11 & 0.56 & 9.09 \\
\hline $\begin{array}{l}\text { Guilt/Shame } \\
\text { (theta-delta) }\end{array}$ & Neuroticism & 4.40 & 0.53 & 8.31 \\
\hline $\begin{array}{c}\text { Anxiety } \\
\text { (theta-delta) }\end{array}$ & Neuroticism & 8.18 & 0.90 & 9.09 \\
\hline $\begin{array}{c}\text { Sales Demand \& Work } \\
\text { Context } \\
\text { ( theta-delta) }\end{array}$ & $\begin{array}{l}\text { Situation-Specific } \\
\text { Affective Beliefs }\end{array}$ & 2.15 & 2.01 & 1.07 \\
\hline $\begin{array}{l}\text { Routine Work } \\
\text { Procedures } \\
\text { ( theta-delta) }\end{array}$ & $\begin{array}{l}\text { Situation-Specific } \\
\text { Affective Beliefs }\end{array}$ & 5.41 & 0.51 & 10.69 \\
\hline $\begin{array}{l}\text { High Pressure } \\
\text { Situations } \\
\text { ( theta-delta) }\end{array}$ & $\begin{array}{l}\text { Situation-Specific } \\
\text { Affective Beliefs }\end{array}$ & 4.43 & 0.48 & 9.33 \\
\hline $\begin{array}{l}\text { Job Dissatisfaction } \\
\text { ( theta-epsilon) }\end{array}$ & $\begin{array}{l}\text { Turnover } \\
\text { Propensity }\end{array}$ & 0.05 & 0.03 & 1.96 \\
\hline $\begin{array}{l}\text { Withdrawal Behaviors } \\
\text { (theta-epsilon) }\end{array}$ & $\begin{array}{l}\text { Turnover } \\
\text { Propensity }\end{array}$ & 5.47 & 0.52 & 10.47 \\
\hline $\begin{array}{l}\text { Negative Job Thoughts } \\
\text { ( theta-epsilon) }\end{array}$ & $\begin{array}{l}\text { Turnover } \\
\text { Propensity }\end{array}$ & 0.33 & 0.04 & 8.51 \\
\hline
\end{tabular}


Mediated Antecedents Model. The Mediated Antecedents Model also provided a good fit to the data as seen in Table 7. Post-hoc modifications were not conducted as the Mediated Antecedent Model provided a good fit of the data to the model.

Table 7

Comparative Fit Indices for the Mediated Antecedents Model

\begin{tabular}{|c|c|c|c|c|c|c|c|}
\hline Model & $\chi^{2}$ & $\overline{D f}$ & $p$ & RMSEA & SRMR & CFI & NNFI \\
\hline $\begin{array}{l}\text { Model 2- } \\
\text { Mediated } \\
\text { Antecedents } \\
\text { Model }\end{array}$ & 90.15 & 51 & $<.01$ & 0.05 & 0.06 & 0.98 & 0.97 \\
\hline
\end{tabular}

Note. p-values are only asymptotically correct under a stringent assumption of multivariate normality and should largely be ignored. RMSEA = Root Mean Square Error of Approximation; SRMR = Standardized Root Mean Square Residual; CFI = Comparative Fit Index; NNFI = Non-normed Fit Index

Results for the Mediated Antecedents Model can be found in Figure 6 and Tables 8 and 9 below. Results indicate that the Correlated Antecedents Model and the Mediated Antecedents Model are equivalent models. The Correlated Antecedents Model aimed to identify the relation between Neuroticism and Situation-specific Affective Beliefs through correlation, whereas the Mediated Antecedents Model aimed at identifying the relationship between Neuroticism and Situationspecific Affective Beliefs through the directional effect of Neuroticism on Situation-specific Affective Beliefs creating two conceptually distinct models. Nevertheless, the empirical evaluation of the models identifies that while they are conceptually distinct models they do not contain enough unique parameritizations to provide empirical distinction and result in the same function of variances and covariances. Essentially, the two different parameterizations result in the same functional set of equations when we set the model implied covariance matrix (as a function of the parameters) equal to the observed covariance matrix. Thus, as seen with the Correlated Antecedents and the Mediated Antecedents Models, equivalent models generate exactly the same values for the model-implied covariance matrix when computed from the parameter estimates; with the same DF, and the model fit for both models is exactly the same. 
Thus, data cannot differentiate between the two models that, by definition, provide exactly the same degree of ability to account for the observed data (MacCallum, Wegener, Uchino, \& Fabrigar, 1993; Raykov \& Marcoulides, 2001).

Results will be explored as proposed, but relationships are identical to the Correlated Antecedents Model as outlined above. Thus, the squared multiple correlations for the indicators of situation-specific affective beliefs are minimal for two out of three indicators not exceeding a commonly accepted cut-off of .32 (Tabachnick \& Fidell, 2007). The latent construct, situationspecific affective beliefs, explained only $8 \%$ percent $\left(R^{2}=0.08\right)$ of the variance in Routine Work Procedures, 18 percent $\left(R^{2}=0.18\right)$ in High Pressure Situations explained, whereas 79 percent $\left(R^{2}\right.$ $=0.79$ ) of the variance in Sales Demands and Work Context was explained. Again, the findings suggests that the three indicators proposed do not sufficiently adhere to explain the latent variable, situation-specific affective beliefs. It still remains noteworthy, however, that the $t$-values are all above 2 . The same can still be said for the latent construct, turnover propensity as two out of the three squared multiple correlations for the indicators of turnover propensity do not exceed a commonly accepted cut-off of .32 (Tabachnick \& Fidell, 2007). The latent construct, turnover propensity, explained 14 percent $\left(R^{2}=0.14\right)$ of the variance in Negative Job Thoughts, 32 percent $\left(R^{2}=0.32\right)$ of the variance in Withdrawal Behaviors, whereas 77 percent $\left(R^{2}=0.77\right)$ of the variance in Job Dissatisfaction was explained. It still remains interesting to note that the $t$-values are all above 2 .

Neuroticism had a direct effect on Turnover Propensity $(\beta=0.22, S E=0.08, t=2.68)$ as hypothesized. The relationship between Neuroticism and Turnover Propensity is consistent with research by Binning et al. (2010) as previously outlined. Neuroticism did not have a direct effect on Situation-Specific Affective Beliefs $(\beta=0.14, S E=0.08, t=1.81)$ as hypothesized explaining only 2 percent of the variance in Situation-specific Affective beliefs $\left(\mathrm{R}^{2}=0.02\right)$. The lack of relationship between Neuroticism and Situation-Specific Affective Beliefs is not consistent with 
findings by Binning et al. (2010) who demonstrated a significant, predictive relationship of neuroticism on situation-specific affective beliefs. Situation-specific Affective Beliefs did have a direct effect on Turnover Propensity as hypothesized $(\beta=0.47, S E=0.12, t=3.96)$ as consistent with Binning et al. (2010) who demonstrated predictive relationships of situation-specific affective beliefs on turnover propensity. The effects of Situation-specific affective beliefs on Turnover Propensity combined with the effects of Neuroticism on Turnover Propensity to explain 23 percent of the variance in Turnover Propensity $\left(R^{2}=0.23\right)$. Ultimately, as Neuroticism does not have a direct effect on Situation-specific Affective Beliefs mediation was not established (Kenny, Kashy, \& Bolger, 1998) and does not support the hypothesized relationships proposed above in Figure 3.

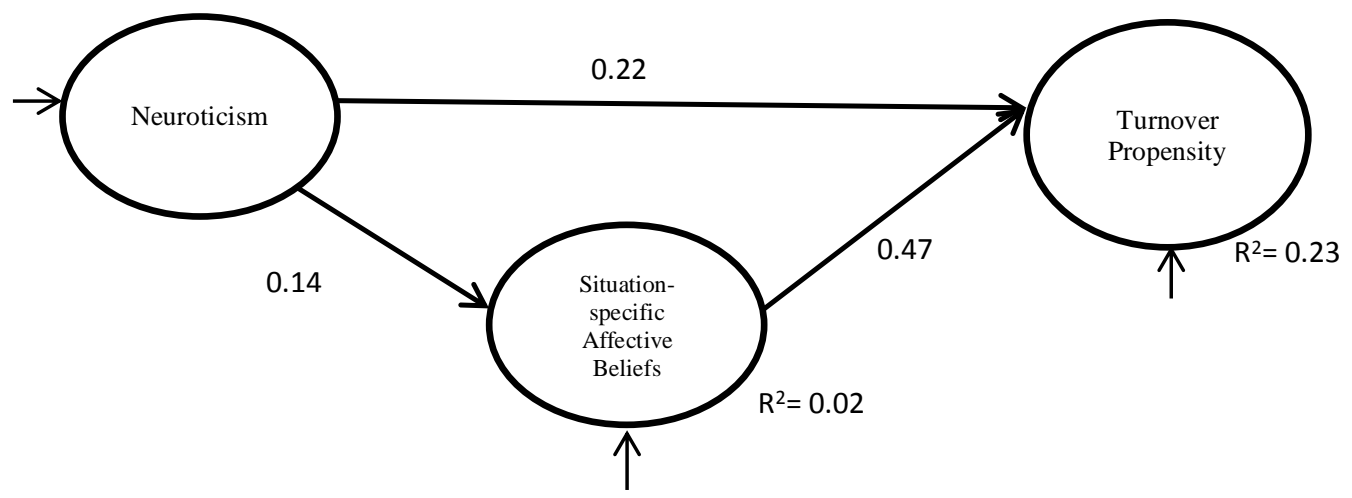

Figure 6. Mediated Antecedent Model Results. 
Table 8

Mediated Antecedents Model: Unstandardized Coefficients, Standard Errors, $t$ values, and $R^{2}$ for Latent Variables

\begin{tabular}{|c|c|c|c|c|c|}
\hline Observer Variable & Latent Variables & B & SE & $t$ & $\mathrm{R}^{2}$ \\
\hline Angry Hostility & Neuroticism & 3.71 & 0.28 & 13.21 & 0.55 \\
\hline Emotional Control & Neuroticism & 2.15 & 0.19 & 11.56 & 0.45 \\
\hline Sadness & Neuroticism & 3.56 & 0.23 & 15.16 & 0.67 \\
\hline Somatic Complaints & Neuroticism & 3.04 & 0.21 & 14.78 & 0.64 \\
\hline Guilt/Shame & Neuroticism & 3.32 & 0.21 & 16.00 & 0.71 \\
\hline Anxiety & Neuroticism & 3.85 & 0.26 & 14.77 & 0.64 \\
\hline $\begin{array}{c}\text { Sales Demand \& Work } \\
\text { Context }\end{array}$ & $\begin{array}{l}\text { Situation-Specific } \\
\text { Affective Beliefs }\end{array}$ & 2.81 & 0.39 & 7.23 & 0.79 \\
\hline $\begin{array}{l}\text { Routine Work } \\
\text { Procedures }\end{array}$ & $\begin{array}{l}\text { Situation-Specific } \\
\text { Affective Beliefs }\end{array}$ & 0.67 & 0.19 & 3.68 & 0.08 \\
\hline $\begin{array}{l}\text { High Pressure } \\
\text { Situations }\end{array}$ & $\begin{array}{l}\text { Situation-Specific } \\
\text { Affective Beliefs }\end{array}$ & 0.99 & 0.19 & 5.18 & 0.18 \\
\hline Job Dissatisfaction & $\begin{array}{l}\text { Turnover } \\
\text { Propensity }\end{array}$ & 0.35 & 0.04 & 8.79 & 0.77 \\
\hline Withdrawal Behaviors & $\begin{array}{l}\text { Turnover } \\
\text { Propensity }\end{array}$ & 0.35 & 0.04 & 7.84 & 0.32 \\
\hline Negative Job Thoughts & $\begin{array}{l}\text { Turnover } \\
\text { Propensity }\end{array}$ & 0.84 & 0.16 & 5.36 & 0.14 \\
\hline
\end{tabular}


Table 9

Mediated Antecedents Model: Theta-Delta \& Theta-Epsilon

\begin{tabular}{|c|c|c|c|c|}
\hline Observer Variable & Latent Construct & $\mathrm{B}$ & SE & $t$ \\
\hline $\begin{array}{l}\text { Angry Hostility } \\
\text { ( theta-delta) }\end{array}$ & Neuroticism & 11.20 & 1.15 & 9.74 \\
\hline $\begin{array}{l}\text { Emotional Control } \\
\text { ( theta-delta) }\end{array}$ & Neuroticism & 5.56 & 0.55 & 10.18 \\
\hline $\begin{array}{l}\text { Sadness } \\
\text { ( theta-delta) }\end{array}$ & Neuroticism & 6.32 & 0.71 & 8.87 \\
\hline $\begin{array}{l}\text { Somatic Complaints } \\
\text { (theta-delta) }\end{array}$ & Neuroticism & 5.11 & 0.56 & 9.09 \\
\hline $\begin{array}{l}\text { Guilt/Shame } \\
\text { (theta-delta) }\end{array}$ & Neuroticism & 4.40 & 0.53 & 8.31 \\
\hline $\begin{array}{l}\text { Anxiety } \\
\text { ( theta-delta) }\end{array}$ & Neuroticism & 8.18 & 0.90 & 9.09 \\
\hline $\begin{array}{c}\text { Sales Demand \& Work } \\
\text { Context } \\
\text { (theta-epsilon) }\end{array}$ & $\begin{array}{l}\text { Situation-Specific } \\
\text { Affective Beliefs }\end{array}$ & 2.15 & 2.01 & 1.07 \\
\hline $\begin{array}{l}\text { Routine Work } \\
\text { Procedures } \\
\text { ( theta-epsilon) }\end{array}$ & $\begin{array}{l}\text { Situation-Specific } \\
\text { Affective Beliefs }\end{array}$ & 5.41 & 0.51 & 10.69 \\
\hline $\begin{array}{l}\text { High Pressure } \\
\text { Situations } \\
\text { ( theta-epsilon) }\end{array}$ & $\begin{array}{l}\text { Situation-Specific } \\
\text { Affective Beliefs }\end{array}$ & 4.43 & 0.48 & 9.33 \\
\hline $\begin{array}{l}\text { Job Dissatisfaction } \\
\text { ( theta-epsilon) }\end{array}$ & $\begin{array}{l}\text { Turnover } \\
\text { Propensity }\end{array}$ & 0.05 & 0.03 & 1.96 \\
\hline $\begin{array}{l}\text { Withdrawal Behaviors } \\
\text { ( theta-epsilon) }\end{array}$ & $\begin{array}{l}\text { Turnover } \\
\text { Propensity }\end{array}$ & 5.47 & 0.52 & 10.47 \\
\hline $\begin{array}{l}\text { Negative Job Thoughts } \\
\text { ( theta-epsilon) }\end{array}$ & $\begin{array}{l}\text { Turnover } \\
\text { Propensity }\end{array}$ & 0.33 & 0.04 & 8.51 \\
\hline
\end{tabular}


Moderated Antecedents Model. Prior to conducting the SEM analysis for this model, orthogonalized indicators were created for the latent interaction construct as outlined by Little, Bovaird, and Widaman (2006). The six unique indicators for Neuroticism and the three indicators for Situation-specific Affective Beliefs were combined to create 18 product terms (the first 18 associated product terms listed in Table 10 provide a comprehensive representation). Table 10 provides a reference for indicators and associated product terms.

Table 10

Orthogonalized Indicator Products

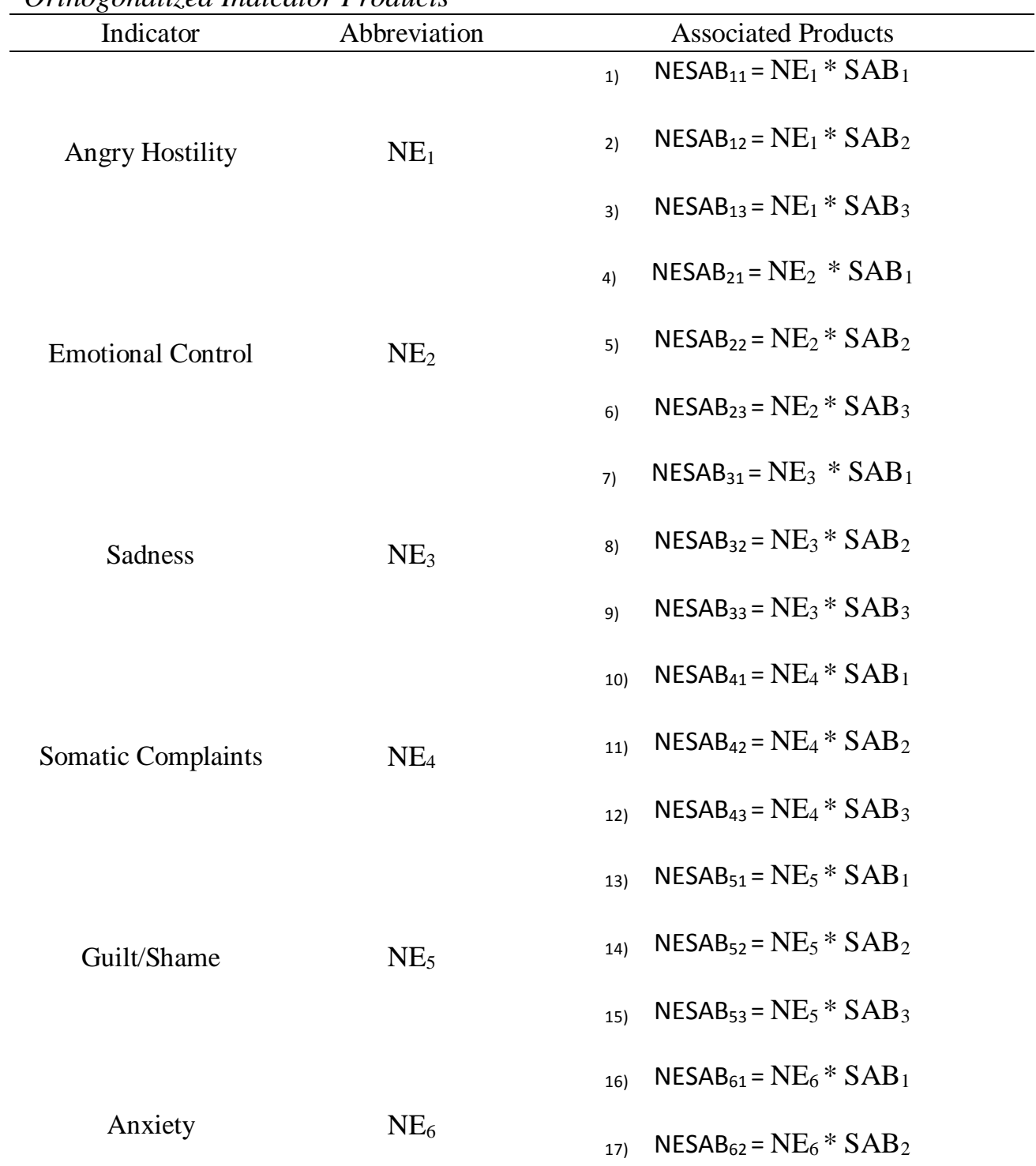


Sales Demand \& Work Context

Routine Work

Procedures

High Pressure Situations
$\mathrm{SAB}_{1}$

$\mathrm{NESAB}_{31}=\mathrm{NE}_{3} * \mathrm{SAB}_{1}$

22) $\mathrm{NESAB}_{41}=\mathrm{NE}_{4} * \mathrm{SAB}_{1}$

23) $\mathrm{NESAB}_{51}=\mathrm{NE}_{5} * \mathrm{SAB}_{1}$

24) $\mathrm{NESAB}_{61}=\mathrm{NE}_{6} * \mathrm{SAB}_{1}$

25) $\mathrm{NESAB}_{12}=\mathrm{NE}_{1} * \mathrm{SAB}_{2}$

26) $\mathrm{NESAB}_{22}=\mathrm{NE}_{2} * \mathrm{SAB}_{2}$

27) $\mathrm{NESAB}_{32}=\mathrm{NE}_{3} * \mathrm{SAB}_{2}$

$\mathrm{SAB}_{2}$

28)

$\mathrm{NESAB}_{42}=\mathrm{NE}_{4} * \mathrm{SAB}_{2}$

$\mathrm{NESAB}_{52}=\mathrm{NE}_{5} * \mathrm{SAB}_{2}$

$\mathrm{NESAB}_{62}=\mathrm{NE}_{6} * \mathrm{SAB}_{2}$

31) $\mathrm{NESAB}_{13}=\mathrm{NE}_{1} * \mathrm{SAB}_{3}$

32) $\mathrm{NESAB}_{23}=\mathrm{NE}_{2} * \mathrm{SAB}_{3}$

33) $\mathrm{NESAB}_{33}=\mathrm{NE}_{3} * \mathrm{SAB}_{3}$

$\mathrm{SAB}_{3}$
34)
$\mathrm{NESAB}_{43}=\mathrm{NE}_{4} * \mathrm{SAB}_{3}$
35)
$\mathrm{NESAB}_{53}=\mathrm{NE}_{5} * \mathrm{SAB}_{3}$
36) 
Next, each of the resulting 18 uncentered product terms was individually regressed onto the first-order effect indicators for each construct. For example,

$$
\mathrm{NESAB}_{11}=\mathrm{b}_{0}+\mathrm{b}_{1} \mathrm{NE}_{1}+\mathrm{b}_{2} \mathrm{NE}_{2}+\mathrm{b}_{3} \mathrm{NE}_{3}+\mathrm{b}_{4} \mathrm{NE}_{4}+\mathrm{b}_{5} \mathrm{NE}_{5}+\mathrm{b}_{6} \mathrm{NE}_{6}+\mathrm{b}_{4} \mathrm{SAB}_{1}+\mathrm{b}_{5} \mathrm{SAB}_{2}+\mathrm{b}_{6} \mathrm{SAB}_{3}
$$

Where $\mathrm{NE}_{1-6}$ and $\mathrm{SAB}_{1-3}$ are the first order indicators for Neuroticism and Situation-specific Affective Beliefs as outlined above. A regression was conducted for each of the 18 uncentered product terms and the residuals were saved and used as indicators of the latent interaction construct, Neuroticism X Situation-specific Affective Beliefs as seen in Figure 4 above. Consistent with Little et al., (2006), Figure 4 displays a representation of the Moderated Antecedents model and includes two important features. First, each of the 18 indicators has unique variance common with other indicators depending on which of the first-order effect indicators was used to create it. Thus, correlations between the residual variances of the interaction indicators must be specified accordingly. The associated product terms for each for each of the nine first order indicators (as seen in Table 9 above) would be allowed to have correlated residuals. For example, the product terms associated with $\mathrm{NE}_{1}$ include $\mathrm{NESAB}_{11}$, $\mathrm{NESAB}_{12}, \mathrm{NESAB}_{13}, \mathrm{NESAB}_{14}, \mathrm{NESAB}_{15}$, and NESAB 16 and each of the six associated product terms were allowed to have correlated measurement errors. Secondly, note that the latent interaction term is not correlated with the main effect variables as the indicators of the interaction term have been orthogonalized creating covariances of zero for the relations between the main effect indicators and the interaction indicators.

The Moderated Antecedents did not provide a good fit to the data as can be seen in Table 11. Post-hoc modifications were not taken into consideration for the Moderated Antecedents Model as the data cannot account for the multitude of parameters estimated for the Moderated Antecedents Model, and, therefore, cannot address the numerous recommended modification 
indices as it is unclear if the estimates are stable to begin with as previously mentioned.

Table 11

Comparative Fit Indices for the Moderated Antecedents Model

\begin{tabular}{|c|c|c|c|c|c|c|c|}
\hline Model & $\chi^{2}$ & $D f$ & $P$ & RMSEA & SRMR & CFI & NNFI \\
\hline $\begin{array}{l}\text { Model 3- } \\
\text { Moderated } \\
\text { Antecedents } \\
\text { Model }\end{array}$ & 1469.07 & 368 & $>0.05$ & 0.13 & 0.15 & 0.84 & 0.81 \\
\hline
\end{tabular}

Note. p-values are only asymptotically correct under a stringent assumption of multivariate normality and should largely be ignored. RMSEA = Root Mean Square Error of Approximation; SRMR = Standardized Root Mean Square Residual; CFI = Comparative Fit Index; NNFI = Non-normed Fit Index;

Results for the Moderated Antecedents Model can be found in Figure 7 and Tables 12, 13, 14, and 15 below. One unexpected consequence of the process used to analyze moderation as outlined by Little et al., (2006) is that the majority of the model parameter estimates are equivalent to the Correlated Antecedents Model and the Mediated Antecedents Model, which is a direct result of the latent interaction term (i.e., NXSAB) not being allowed to correlate with the main effect variables (i.e., Neuroticism and Situation-affective Beliefs) as the indicators of the interaction term have been orthogonalized creating covariances of zero for the relations between the main effect indicators and the interaction indicators as previously noted.

Thus, it remains difficult to determine the interpretability of the relationships discovered in Figure 7 as the squared multiple correlations for the indicators of situation-specific affective beliefs are minimal for two out of three indicators, while t-values are above 2. Furthermore, the same can still be said for the latent construct of turnover propensity. The squared multiple correlations for the indicators of turnover propensity are minimal for two out of three indicators, while the $t$-values are all above 2 .

Results will be explored as proposed. Consistent with my hypotheses, Neuroticism (B = $0.22, S E=0.08, t=2.68)$, and Situation-Specific Affective Beliefs $(\mathrm{B}=0.47, S E=0.12, t=3.96)$ 
predicted Turnover Propensity. As previously outlined, these relationships are consistent with research by Binning et al. (2010). NXSAB $(\mathrm{B}=0.06, S E=0.08, t=0.82)$ did not predict Turnover Propensity as hypothesized. Overall, the effects on Turnover Propensity explained 23 percent of the variance in Turnover Propensity $\left(\mathrm{R}^{2}=0.23\right)$. Furthermore, Neuroticism did not relate to Situation-specific Affective Beliefs as hypothesized $(\mathrm{B}=0.14, S E=0.08, t=1.81)$, which remains inconsistent with findings by Binning et al (2010). Consequently, results do not support moderation as proposed in Figure 4 above.

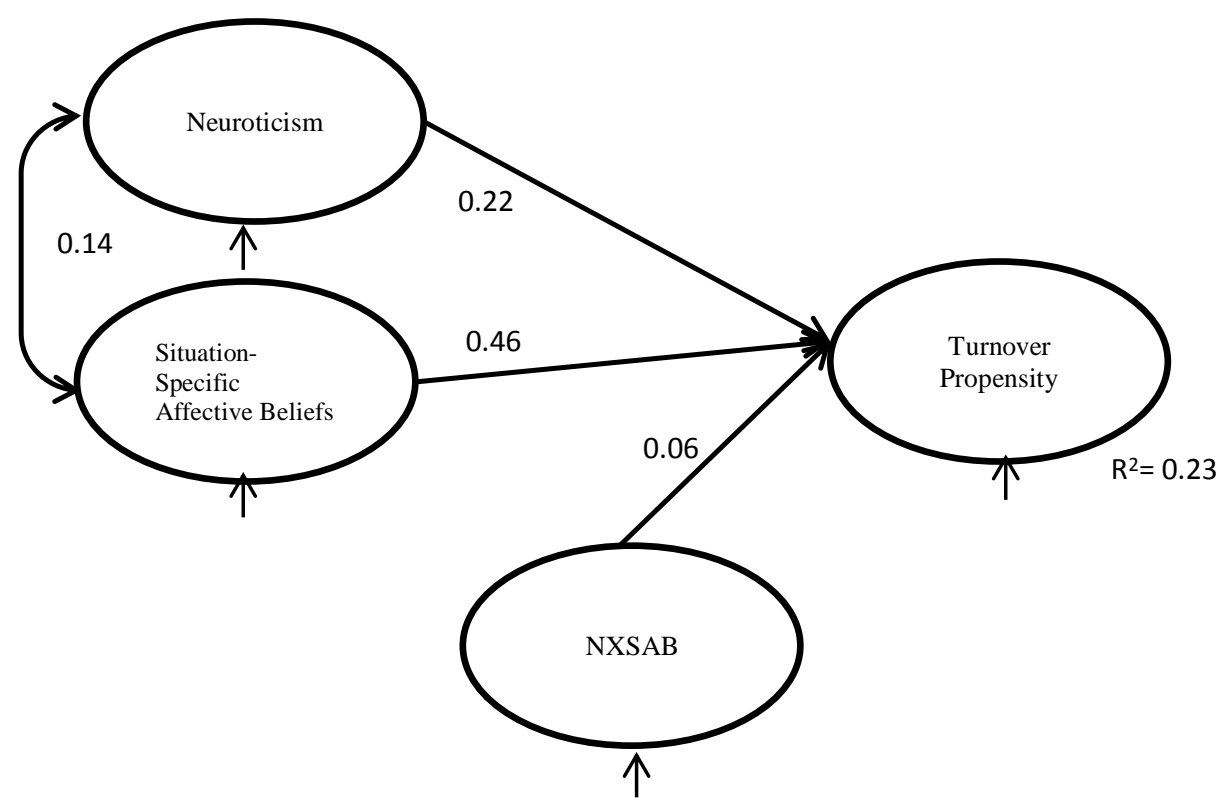

Note: NXSAB represents the interaction of Neuroticism and Situation-specific Affective beliefs.

Figure 7. Moderated Antecedent Model Results. 
Table 12

Moderated Antecedents Model: Unstandardized Coefficients, Standard Errors, $t$ values, and $R^{2}$ for Latent Variables

\begin{tabular}{|c|c|c|c|c|c|}
\hline Observer Variable & Latent Variables & $\mathrm{B}$ & $\mathrm{SE}$ & $t$ & $\mathrm{R}^{2}$ \\
\hline Angry Hostility & Neuroticism & 3.71 & 0.28 & 13.21 & 0.55 \\
\hline Emotional Control & Neuroticism & 2.15 & 0.19 & 11.56 & 0.45 \\
\hline Sadness & Neuroticism & 3.56 & 0.23 & 15.16 & 0.67 \\
\hline Somatic Complaints & Neuroticism & 3.04 & 0.21 & 14.78 & 0.64 \\
\hline Guilt/Shame & Neuroticism & 3.32 & 0.21 & 16.00 & 0.71 \\
\hline Anxiety & Neuroticism & 3.85 & 0.26 & 14.77 & 0.64 \\
\hline $\begin{array}{c}\text { Sales Demand \& Work } \\
\text { Context }\end{array}$ & $\begin{array}{l}\text { Situation-Specific } \\
\text { Affective Beliefs }\end{array}$ & 2.81 & 0.39 & 7.23 & 0.79 \\
\hline Routine Work Procedures & $\begin{array}{l}\text { Situation-Specific } \\
\text { Affective Beliefs }\end{array}$ & 0.67 & 0.19 & 3.68 & 0.08 \\
\hline High Pressure Situations & $\begin{array}{l}\text { Situation-Specific } \\
\text { Affective Beliefs }\end{array}$ & 0.99 & 0.19 & 5.18 & 0.18 \\
\hline Job Dissatisfaction & Turnover Propensity & 0.35 & 0.04 & 8.79 & 0.77 \\
\hline Withdrawal Behaviors & Turnover Propensity & 0.35 & 0.04 & 7.84 & 0.32 \\
\hline Negative Job Thoughts & Turnover Propensity & 0.84 & 0.16 & 5.36 & 0.14 \\
\hline $\mathrm{NESAB}_{11}$ & NXSAB & 4.80 & 0.86 & 5.61 & 0.13 \\
\hline $\mathrm{NESAB}_{12}$ & NXSAB & 0.89 & 0.63 & 1.42 & 0.01 \\
\hline $\mathrm{NESAB}_{13}$ & NXSAB & 11.02 & 0.91 & 12.04 & 0.67 \\
\hline $\mathrm{NESAB}_{21}$ & NXSAB & 2.65 & 0.76 & 3.47 & 0.05 \\
\hline $\mathrm{NESAB}_{22}$ & NXSAB & 0.82 & 0.52 & 1.60 & 0.01 \\
\hline $\mathrm{NESAB}_{23}$ & NXSAB & 5.01 & 0.46 & 10.85 & 0.40 \\
\hline $\mathrm{NESAB}_{31}$ & NXSAB & 4.53 & 0.97 & 4.69 & 0.09 \\
\hline $\mathrm{NESAB}_{32}$ & NXSAB & 1.48 & 0.57 & 2.57 & 0.03 \\
\hline $\mathrm{NESAB}_{33}$ & NXSAB & 9.98 & 0.55 & 18.25 & 0.82 \\
\hline $\mathrm{NESAB}_{41}$ & NXSAB & 2.94 & 0.75 & 3.94 & 0.06 \\
\hline $\mathrm{NESAB}_{42}$ & NXSAB & 1.65 & 0.57 & 2.89 & 0.04 \\
\hline $\mathrm{NESAB}_{43}$ & NXSAB & 8.41 & 0.49 & 17.00 & 0.75 \\
\hline $\mathrm{NESAB}_{51}$ & NXSAB & 2.88 & 0.79 & 3.65 & 0.06 \\
\hline $\mathrm{NESAB}_{52}$ & NXSAB & 1.57 & 0.57 & 2.74 & 0.03 \\
\hline
\end{tabular}




\begin{tabular}{llcccc} 
NESAB $_{53}$ & NXSAB & 8.83 & 0.50 & 17.51 & 0.78 \\
NESAB $_{61}$ & NXSAB & 3.25 & 0.93 & 3.49 & 0.05 \\
NESAB $_{62}$ & NXSAB & 2.15 & 0.64 & 3.37 & 0.05 \\
NESAB $_{63}$ & NXSAB & 10.28 & 0.65 & 15.83 & 0.69 \\
\hline
\end{tabular}

Table 13

Moderated Antecedents Model: Theta-Delta \& Theta-Epsilon of Main Effect Latent Variables Only

\begin{tabular}{|c|c|c|c|c|}
\hline Observer Variable & Latent Construct & B & SE & $t$ \\
\hline $\begin{array}{l}\text { Angry Hostility } \\
\text { (theta-delta) }\end{array}$ & Neuroticism & 11.20 & 1.15 & 9.74 \\
\hline $\begin{array}{l}\text { Emotional Control } \\
\text { (theta-delta) }\end{array}$ & Neuroticism & 5.56 & 0.55 & 10.18 \\
\hline $\begin{array}{c}\text { Sadness } \\
\text { (theta-delta) }\end{array}$ & Neuroticism & 6.32 & 0.71 & 8.87 \\
\hline $\begin{array}{l}\text { Somatic Complaints } \\
\text { (theta-delta) }\end{array}$ & Neuroticism & 5.11 & 0.56 & 9.09 \\
\hline $\begin{array}{l}\text { Guilt/Shame } \\
\text { (theta-delta) }\end{array}$ & Neuroticism & 4.40 & 0.53 & 8.31 \\
\hline $\begin{array}{c}\text { Anxiety } \\
\text { (theta-delta) }\end{array}$ & Neuroticism & 8.18 & 0.90 & 9.09 \\
\hline $\begin{array}{c}\text { Sales Demand \& Work } \\
\text { Context } \\
\text { (theta-delta) }\end{array}$ & $\begin{array}{l}\text { Situation-Specific } \\
\text { Affective Beliefs }\end{array}$ & 2.15 & 2.01 & 1.07 \\
\hline $\begin{array}{c}\text { Routine Work Procedures } \\
\text { (theta-delta) }\end{array}$ & $\begin{array}{l}\text { Situation-Specific } \\
\text { Affective Beliefs }\end{array}$ & 5.41 & 0.51 & 10.69 \\
\hline $\begin{array}{l}\text { High Pressure Situations } \\
\text { (theta-delta) }\end{array}$ & $\begin{array}{l}\text { Situation-Specific } \\
\text { Affective Beliefs }\end{array}$ & 4.43 & 0.48 & 9.33 \\
\hline $\begin{array}{l}\text { Job Dissatisfaction } \\
\text { (theta-epsilon) }\end{array}$ & Turnover Propensity & 0.05 & 0.03 & 1.96 \\
\hline $\begin{array}{l}\text { Withdrawal Behaviors } \\
\text { (theta-epsilon) }\end{array}$ & Turnover Propensity & 5.47 & 0.52 & 10.47 \\
\hline $\begin{array}{l}\text { Negative Job Thoughts } \\
\text { (theta-epsilon) }\end{array}$ & Turnover Propensity & 0.33 & 0.04 & 8.51 \\
\hline
\end{tabular}


Table 14

Moderated Antecedents Model: Theta-Deltas for

Interaction Latent Variable Only

\begin{tabular}{|c|c|c|c|c|c|c|c|c|c|}
\hline Indicator & $\begin{array}{c}\text { NESAB } \\
11\end{array}$ & $\begin{array}{c}\text { NESAB } \\
12\end{array}$ & $\begin{array}{c}\text { NESAB } \\
13\end{array}$ & $\begin{array}{c}\text { NESAB } \\
21\end{array}$ & $\begin{array}{c}\text { NESAB } \\
22\end{array}$ & $\begin{array}{c}\text { NESAB } \\
23\end{array}$ & $\begin{array}{c}\text { NESAB } \\
31 \\
\end{array}$ & $\begin{array}{c}\text { NESAB } \\
32\end{array}$ & $\begin{array}{c}\text { NESAB } \\
33\end{array}$ \\
\hline $\begin{array}{c}\text { NESAB } \\
11\end{array}$ & $\begin{array}{l}159.28 \\
13.69 \\
\mathbf{1 1 . 6 3}\end{array}$ & & & & & & & & \\
\hline $\begin{array}{c}\text { NESAB } \\
12\end{array}$ & $\begin{array}{c}21.13 \\
6.06 \\
\mathbf{3 . 4 9}\end{array}$ & $\begin{array}{c}90.59 \\
7.95 \\
\mathbf{1 1 . 4 0}\end{array}$ & & & & & & & \\
\hline $\begin{array}{c}\text { NESAB } \\
13\end{array}$ & $\begin{array}{c}37.61 \\
6.06 \\
\mathbf{3 . 4 9}\end{array}$ & $\begin{array}{l}7.18 \\
4.29 \\
\mathbf{1 . 6 7}\end{array}$ & $\begin{array}{c}60.31 \\
14.02 \\
\mathbf{4 . 3 0}\end{array}$ & & & & & & \\
\hline $\begin{array}{c}\text { NESAB } \\
21\end{array}$ & $\begin{array}{c}34.24 \\
6.95 \\
4.92\end{array}$ & & & $\begin{array}{c}132.32 \\
11.73 \\
\mathbf{1 1 . 2 8}\end{array}$ & & & & & \\
\hline $\begin{array}{c}\text { NESAB } \\
22\end{array}$ & & $\begin{array}{l}31.84 \\
4.88 \\
\mathbf{6 . 5 3}\end{array}$ & & $\begin{array}{c}14.87 \\
5.08 \\
\mathbf{2 . 9 3}\end{array}$ & $\begin{array}{c}61.60 \\
5.53 \\
\mathbf{1 1 . 1 5}\end{array}$ & & & & \\
\hline $\begin{array}{c}\text { NESAB } \\
23\end{array}$ & & & $\begin{array}{l}0.31 \\
3.60 \\
\mathbf{0 . 0 9}\end{array}$ & $\begin{array}{c}34.92 \\
4.96 \\
\mathbf{7 . 0 4}\end{array}$ & $\begin{array}{l}3.61 \\
2.80 \\
\mathbf{1 . 2 9}\end{array}$ & $\begin{array}{c}37.62 \\
3.52 \\
\mathbf{1 0 . 6 7}\end{array}$ & & & \\
\hline $\begin{array}{c}\text { NESAB } \\
31\end{array}$ & $\begin{array}{l}16.44 \\
7.66 \\
\mathbf{2 . 1 5}\end{array}$ & & & & & & $\begin{array}{c}202.05 \\
18.30 \\
\mathbf{1 1 . 0 4}\end{array}$ & & \\
\hline $\begin{array}{c}\text { NESAB } \\
32\end{array}$ & & $\begin{array}{l}7.78 \\
4.88 \\
\mathbf{1 . 8 9}\end{array}$ & & & & & $\begin{array}{c}42.17 \\
8.16 \\
\mathbf{5 . 1 7}\end{array}$ & $\begin{array}{c}73.94 \\
6.67 \\
\mathbf{1 1 . 0 8}\end{array}$ & \\
\hline $\begin{array}{c}\text { NESAB } \\
{ }_{33}\end{array}$ & & & $\begin{array}{l}3.15 \\
5.86 \\
0.54\end{array}$ & & & & $\begin{array}{l}34.96 \\
5.53 \\
\mathbf{6 . 3 2}\end{array}$ & $\begin{array}{c}14.55 \\
3.11 \\
\mathbf{4 . 6 8}\end{array}$ & $\begin{array}{c}21.28 \\
2.77 \\
\mathbf{7 . 6 9}\end{array}$ \\
\hline $\begin{array}{c}\text { NESAB } \\
41\end{array}$ & $\begin{array}{l}8.12 \\
5.82 \\
\mathbf{1 . 3 9}\end{array}$ & & & & & & & & \\
\hline $\begin{array}{c}\text { NESAB } \\
42\end{array}$ & & $\begin{array}{l}6.43 \\
3.77 \\
\mathbf{1 . 7 0}\end{array}$ & & & & & & & \\
\hline $\begin{array}{c}\text { NESAB } \\
43\end{array}$ & & & $\begin{array}{l}0.39 \\
5.20 \\
\mathbf{0 . 0 7}\end{array}$ & & & & & & \\
\hline $\begin{array}{c}\text { NESAB } \\
51\end{array}$ & $\begin{array}{c}55.55 \\
8.61 \\
6.45\end{array}$ & & & & & & & & \\
\hline $\begin{array}{c}\text { NESAB } \\
52\end{array}$ & & $\begin{array}{l}11.55 \\
4.36 \\
\mathbf{2 . 6 5}\end{array}$ & & & & & & & \\
\hline $\begin{array}{c}\text { NESAB } \\
53\end{array}$ & & & $\begin{array}{l}2.78 \\
5.64 \\
\mathbf{0 . 4 9}\end{array}$ & & & & & & \\
\hline $\begin{array}{c}\text { NESAB } \\
61\end{array}$ & $\begin{array}{c}22.50 \\
8.49 \\
\mathbf{2 . 6 5}\end{array}$ & & & & & & & & \\
\hline $\begin{array}{c}\text { NESAB } \\
62\end{array}$ & & $\begin{array}{l}16.31 \\
4.39 \\
\mathbf{3 . 3 1}\end{array}$ & & & & & & & \\
\hline $\begin{array}{c}\text { NESAB } \\
63\end{array}$ & & & $\begin{array}{l}5.63 \\
6.84 \\
\mathbf{0 . 8 2}\end{array}$ & & & & & & \\
\hline
\end{tabular}

Note: Plain text numbers $=$ unstandardized coefficients; Italicized Numbers $=$ standard errors; Bold Numbers $=t$-value 
Table 15

Moderated Antecedents Model: Theta-Delta \&

Theta-Epsilon Interaction Latent Variable Only

\begin{tabular}{|c|c|c|c|c|c|c|c|c|c|}
\hline Indicator & $\begin{array}{c}\text { NESAB } \\
41\end{array}$ & $\begin{array}{c}\text { NESAB } \\
42\end{array}$ & $\begin{array}{c}\text { NESAB } \\
43\end{array}$ & $\underset{51}{\text { NESAB }}$ & $\begin{array}{c}\text { NESAB } \\
52\end{array}$ & $\begin{array}{c}\text { NESAB } \\
53\end{array}$ & $\begin{array}{c}\text { NESAB } \\
61\end{array}$ & $\begin{array}{c}\text { NESAB } \\
62\end{array}$ & $\begin{array}{c}\text { NESAB } \\
63\end{array}$ \\
\hline $\begin{array}{c}\text { NESAB } \\
41\end{array}$ & $\begin{array}{l}125.24 \\
11.32 \\
\mathbf{1 1 . 0 6}\end{array}$ & & & & & & & & \\
\hline $\begin{array}{c}\text { NESAB } \\
42\end{array}$ & $\begin{array}{c}50.89 \\
6.93 \\
\mathbf{7 . 3 4}\end{array}$ & $\begin{array}{c}74.50 \\
6.72 \\
\mathbf{1 1 . 0 9}\end{array}$ & & & & & & & \\
\hline $\begin{array}{c}\text { NESAB } \\
43\end{array}$ & $\begin{array}{c}15.04 \\
3.90 \\
\mathbf{3 . 8 6}\end{array}$ & $\begin{array}{l}6.96 \\
2.91 \\
\mathbf{2 . 3 9}\end{array}$ & $\begin{array}{c}23.00 \\
2.54 \\
9.06\end{array}$ & & & & & & \\
\hline $\begin{array}{c}\text { NESAB } \\
51\end{array}$ & & & & $\begin{array}{c}140.43 \\
12.53 \\
\mathbf{1 1 . 2 1}\end{array}$ & & & & & \\
\hline $\begin{array}{c}\text { NESAB } \\
52\end{array}$ & & & & $\begin{array}{c}18.64 \\
5.99 \\
\mathbf{3 . 1 1}\end{array}$ & $\begin{array}{c}74.85 \\
6.75 \\
\mathbf{1 1 . 0 9}\end{array}$ & & & & \\
\hline $\begin{array}{c}\text { NESAB } \\
53\end{array}$ & & & & $\begin{array}{c}14.79 \\
3.70 \\
\mathbf{3 . 9 9}\end{array}$ & $\begin{array}{l}12.60 \\
2.88 \\
\mathbf{4 . 3 8}\end{array}$ & $\begin{array}{c}21.60 \\
2.50 \\
\mathbf{8 . 6 3}\end{array}$ & & & \\
\hline $\begin{array}{c}\text { NESAB } \\
61\end{array}$ & & & & & & & $\begin{array}{c}196.38 \\
17.73 \\
\mathbf{1 1 . 0 8}\end{array}$ & & \\
\hline $\begin{array}{c}\text { NESAB } \\
62\end{array}$ & & & & & & & $\begin{array}{c}32.27 \\
8.60 \\
\mathbf{3 . 7 5}\end{array}$ & $\begin{array}{c}92.80 \\
8.37 \\
\mathbf{1 1 . 0 9}\end{array}$ & \\
\hline $\begin{array}{c}\text { NESAB } \\
63\end{array}$ & & & & & & & $\begin{array}{c}18.35 \\
6.51 \\
\mathbf{2 . 8 2}\end{array}$ & $\begin{array}{c}13.84 \\
4.41 \\
\mathbf{3 . 1 4}\end{array}$ & $\begin{array}{c}47.37 \\
4.91 \\
\mathbf{9 . 6 5}\end{array}$ \\
\hline
\end{tabular}

Note: Plain text numbers $=$ unstandardized coefficients; Italicized Numbers = standard errors; Bold Numbers $=t$-value 


\section{Summary of Results}

The Correlated Antecedents Model and the Mediated Antecedents Model provided a good fit to the data, and the Moderated Antecedents Model did not. Results indicate that the Correlated Antecedents Model and the Mediated Antecedents Model are equivalent models. The Correlated Antecedents Model aimed to identify the relationship between Neuroticism and Situation-specific Affective Beliefs through correlation, whereas the Mediated Antecedents Model aimed at identifying the relationship between Neuroticism and Situation-specific Affective Beliefs through the direct effect of Neuroticism on Situation-specific Affective Beliefs to explore mediation creating two conceptually distinct models. As outlined above, the empirical evaluation of the models identifies that the two conceptually distinct models simply do not contain enough unique parameritizations resulting in the same function of variances and covariances.

The Moderated Antecedents Model did not provide a good fit to the data as none of the fit indices indicated acceptable fit and the model did not meet the recommended requirements of 8 to10 participants per 1 parameter estimate. Moreover, the Moderated Antecedents Model contains numerous equivalent estimated model parameters as the other models with the exception of the parameter estimates of the direct effect of the orthogonal, latent interaction variable, NXSAB, on Turnover Propensity as the process outlined by Little et al. (2006) requires orthogonalization of the latent interaction variable, NXSAB. Results provide additional insight into work done by Binning et al. (2010), which I will discuss in turn below. 


\section{CHAPTER IV}

\section{DISCUSSION AND CONCLUSIONS}

The three latent structural models proposed within the present study shed some additional light onto different affective belief systems and how they relate to turnover propensity. My goal was to explore neuroticism and situation-specific affective beliefs to inform Human Resource practitioners and organizational researchers how these affective belief systems interact to predict turnover propensity in greater detail. Both the Correlated Antecedents and the Moderated Antecedents model fit the data as proposed, whereas the Moderated Antecedents Model did not fit the data as proposed. Results from the Moderated Antecedents Model suggest that situationspecific beliefs do not seem to be an important construct in understanding the direction and strength of the relation between neuroticism and turnover propensity, but the lack of a sufficient sample size certainly makes it difficult to fully understand the findings of the Moderated Antecedents Model. Nevertheless, the proposed relationships provide additional support for work done by Binning et al. (2010) as neuroticism and situation-specific affective beliefs continue to play distinguishable roles in explaining turnover propensity.

First, the present study supports findings by Binning et al. (2010) indicating that retail sales associates higher in neuroticism tend to be more tense, self-critical and moody across a variety of situations and have a greater likelihood to actually turnover. Second, individuals reporting frustration associated with the demands of retail sales have a greater proclivity to turnover as consistent with Binning et al. Neuroticism and situation-specific affective beliefs clearly lead to a greater understanding of who has the likelihood to turnover. The issue, however, 
of determining whether or not the relationship between neuroticism and situation-specific affective beliefs is directional or non-directional could not be resolved. Those higher in neuroticism were not higher in situation-specific affective beliefs, and neuroticism did not predict situation-specific affective beliefs as hypothesized, which is not consistent with previous research by Binning et al.

Structural Equation Modeling is a powerful technique for testing the proposed measurement model of latent variables depicting the pattern of observed variables for latent constructs in a hypothesized model (Schrieber et al, 2006). The hypothesized indicators for the latent constructs including situation-specific affective beliefs and turnover propensity did not fully cohere to represent the proposed, latent constructs. The latent construct, situation-specific affective beliefs, was proposed to represent individual beliefs about how specific situations will create opportunities for certain affective reactions. The proposed indicators including, sales demands and work contexts, high pressure situations, and routine work procedures are factors representing an employee's beliefs regarding which job-specific situations have the propensity to create job frustration (Binning et al., 2010), but the proposed latent variable did not cohere to represent the these factors as strongly as expected. Thus, findings lead to the possibility that sales demands and work contexts, high pressure situations, and routine work procedures should be evaluated as three separate factors of situation-specific affective beliefs as originally evaluated by Binning et al.

Evaluating the indicators of the latent construct, situation-specific affective beliefs, separately may represent better the intricacies associated with specific work related situations and may be important for understanding what situations employees find more frustrating than others. For example, retail sales representative's frustrations for job demands relating to sales demands and work context provided the greatest association with the latent construct, situation-specific 
affective beliefs. Sales demands and work contexts include retail sales associate's self-reported frustrations across a series of job-specific dimensions such as performance management, selling process, customer service, and irregular work schedule. Binning et al. (2010) suggested that retail sales representatives may find certain job-specific situations more affectively evocative than others as they discovered that retail sales representatives higher in neuroticism also reported that they are more frustrated regarding sales demands and work contexts. The relationship between neuroticism and situation-specific affective beliefs reported by Binning et al. (2010) may explain why sales demands and work contexts surfaced with the greatest association with the proposed latent variable, situation-specific affective beliefs. Ultimately, retail sales associate's affective beliefs of job-specific frustrations may provide interesting insight into which job specific situations are more affectively evocative to those higher in neuroticism.

Similarly, the latent construct, turnover propensity, was proposed to represent the proclivity of an employee to voluntarily turnover. Job dissatisfaction, negative job thoughts, and withdrawal behaviors are consistent with an employee's proclivity to actually turnover, but the latent turnover propensity did not fully cohere to explain the association of the hypothesized indicators. Again, this lack of coherence may suggest that each indicator should be evaluated separately. Research by LeBreton et al. (2004) supports this contention as they found that turnover related criteria can be arranged in rough causal order, from the most distal to most proximal with regard to their relationship to actual turnover as seen in Figure 8 below.

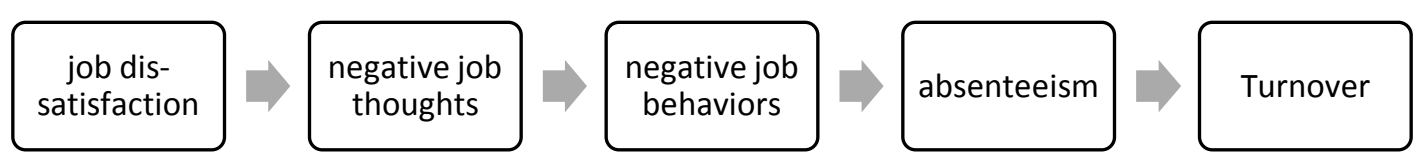

Figure 8. Rough Causal Order of Turnover Related Criterion. 


\section{Implications for Practice}

Evidence seems to suggest that, within retail sales environments, sales demands and work contexts create more affectively evocative responses from retail sales associates higher in neuroticism than do high pressure situations and routine work procedures and Human Resource professionals may benefit from this understanding. Decision making within pre-employment contexts should place greater emphasis on job-specific dimensions associated with sales demands and work context including dimensions such as performance management, selling process, and customer service to aid in determining who to may have the greater likelihood to turnover. For example, if a given applicant has a response pattern consistent with neuroticism and reports frustrations associated with sales demands and work contexts it stands to reason that this applicant will not tolerate the demands of performing as a retail sales associate and should not be hired as they will have a higher likelihood to turnover.

Additionally, the present study provides support that job dissatisfaction continues to be an important, affectively laden indicator to understand turnover propensity. Job dissatisfaction has traditionally been described as an affectively laden construct (see Weiss, 2002) and has significant relationships with neuroticism (LeBreton et al, 2004; Zimmerman, et al., 2008). Weiss (2002) tried to shed some light on the affective state of job satisfaction defining job satisfaction as “a positive (or negative) evaluative judgment one makes about one's job or job situation.” (p 175; Weiss, 2002). Thus, job satisfaction is not the direct measurement of affect, but an evaluative, attitudinal response to a more global understanding of an individual's beliefs regarding one's job or job situations. Weiss' (2002) definition of job dissatisfaction is consistent with Robinson and Clore's (2002) evaluations of self-reports of affective experiences. If job dissatisfaction is a global evaluation of negative judgments one makes about one's job or job situations then this evaluation is based on the recall of semantic memory processes and not of online emotional 
reactions. In the end, turnover is disruptive and costly, and job dissatisfaction should continue to be taken into consideration as an affective, proximal outcome to actual turnover as it is increasingly clear that affect plays an important role in understanding turnover (Morrell, et al., 2004).

\section{Limitations}

A major limitation of the current study was the inability to acquire a larger sample size (n 2000) as originally proposed. Thus, I was unable to bifurcate the sample to perform two stages of analysis including a model development stage and a model testing and validation stage. Nevertheless, the sample size obtained $(\mathrm{N}=247)$ provided ample power for stable parameter estimates of the Correlated Antecedents Model and the Mediated Antecedents Model. Unfortunately, the sample did not provide enough power for the Moderated Antecedents Model and, therefore, results did not provide stable parameter estimates and the model did not indicate a good fit to the data.

The self-report methodology regarding affective assessments was elaborated in great detail above as consistent with work by Robinson and Clore (2002), but, nevertheless, self-report contexts provide minimal control for the variables of interest and therefore remain open for single-method bias correlational in nature and response distortion. Also, most of the participants in this study were European American, and all participants are from the same telecommunications company within the retail sales representative occupation. Future research should be undertaken which utilizes samples that are more diverse in order to understand how consistent and generalizable the results of this study are. Finally, the reported coefficient alphas of the situationspecific affective beliefs factor, routine work procedures, are low. Binning et al. (2010) reported coefficient alphas from samples of 2,030 (and 247) at .57 (.56), respectively, and the present study replicated a coefficient alpha .56 with the sample of 247 . Thus, the finding lead me to 
suggest the routine work procedures may not fully cohere as a factor of situation-specific affective beliefs and may lend reason as to why the higher-order latent, construct, situationspecific affective beliefs did not fully cohere within the present study.

\section{Directions for Future Research}

Assessing situation-specific affective functioning is consistent with an interactionist perspective. Many endorse an interactionist paradigm (Binning, LeBreton, \& Adorno, 2006; Tett, \& Burnett, 2003; Tinsley, 2000), yet there is relatively less research and theory on situationspecific affect and its role in voluntary turnover. In their explication of Affective Events Theory, Weiss and Cropanzano (1996) state that for a person to experience an emotion, an event in the individual's environment has to be appraised. Individuals may develop situation-specific beliefs based on repeated experience of emotions to non-work and work situations and then, at some point in time, these general beliefs can be assessed as a basis for projecting future reactions to similar situations. Future research should move towards developing a theory of how affective belief systems relate to more episodically-dependent online emotional experiences. For example, experiments should be conducted to determine if those higher in neuroticism actually react more negatively to certain job situations over others and which online emotional reactions are associated with these reactions. In turn, researchers would be able to confirm if retail sales associates that are higher in neuroticism also react more negatively to demands associated with performance management, selling process, customer service, and irregular work schedules and what online emotional reactions are associated with these interactions.

Additional data already collected in a number of other job settings should continue to be evaluated as consistent with work by Binning et al. (2010) and the present study to evaluate if a coherent structure of situation-specific affective beliefs emerge empirically from job candidate frustration ratings in other job settings, and if particular situation-specific affective beliefs relate 
to and are predicted by employees reports of neuroticism. Actual turnover data also provides more opportunity to test further the predictive value of these affective constructs. Furthermore, evaluations of situation-specific affective beliefs and their relationship to neuroticism and other Big 5 traits might provide additional insight into predicting what job-specific demands certain employees believe to be most frustrating. Finally, future research may benefit from moving to a granular level of detail by examining the relationships of the facets of neuroticisms with factors of situation-specific affective beliefs creating greater specificity in outlining what facets of neuroticism best explain the predictive relationship between neuroticism and situation specific affective beliefs.

\section{Concluding Remarks}

The present study did provide additional insight into how affective belief systems relate to turnover propensity as originally proposed through evaluating three, hypothesized structural models reinforcing and expanding upon previous research by Binning et al. (2010). Neuroticism and situation-specific affective beliefs play distinguishable roles in explaining turnover propensity. Research by Binning et al. (2010) and the present study certainly make it increasingly clear that understanding how affective belief systems relate to turnover propensity can increase our understanding of what employees have the proclivity to actually turnover and, in turn, aid in reducing the costs and disruptions associated with turnover for organizations and employees alike. 


\section{REFERENCES}

Adorno, A.J., \& Binning, J.F. (2001). Reducing call center employee turnover. In N.L. Petouhoff (Ed.), In Action: Recruiting, training, and evaluating call center employees. Alexandria, VA: American Society for Training and Development.

Barrick, M.R., \& Zimmerman, R.D., (2005) Reducing voluntary, avoidable turnover through selection. Journal of Applied Psychology, 90, 159-166.

Binning, J.F., \& Bradshaw, A.L. (2012; April). A source trait conceptualization of person-work environment fit. Paper accepted for presentation at the Annual Conference of the Society for Industrial and Organizational Psychology, San Diego, CA.

Binning, J.F., Bradshaw, A.L., LeBreton, J.M., \& Scheier, K.T. (2010; April). Understanding turnover propensity via job-specific and identity-based emotional beliefs. Paper presented at the Annual Conference of the Society for Industrial and Organizational Psychology, Atlanta, GA.

Bollen, K. A. (1989). Structural Equations with Latent Variables. New York: John Wiley \& Sons, Inc.

Bono, J. E., \& Judge, T. A. (2003). Core self-evaluations: A review of the trait and its role in job satisfaction and job performance. European Journal of Personality, 17, S5-S18.

Brief, A.P., \& Weiss, H.M. (2002). Organizational behavior: Affect in the workplace. Annual Review of Psychology, 53, 279-307.

Cascio, F.W. (1991). Managing Human Resources: Productivity, Quality of Work Life and Profits, $\left(3^{\text {rd }}\right.$ Ed. $)$ New York: McGraw Hill.

Christiansen, N. D., \& Tett, R. P. (2008) Toward a better understanding of the role of situations in linking personality, work behavior, and job performance. Industrial and Organizational Psychology: Perspectives on Science and Practice, 3, 312-316.

Clark, L. A., \& Watson, D. (1999). Temperament: A new paradigm for trait psychology. In L. A. Pervin \& O. P. John (Eds.), Handbook of personality: Theory and research (2nd ed., pp. 399-423). New York: Guilford.

Cole, D.A. (1987). Utility of confirmatory factor analysis in test validation research. Journal of Consulting and Clinical Psychology, 55, 584-594. 
Connolly, J. J., \& Viswesvaran, C. (2000). The role of affectivity in job satisfaction: A metaanalysis. Personality and individual differences, 29(2), 265-281.

Funder, D.C. (2008). Persons, situations and person-situation interactions. In O.P. John, R. Robins \& L. Pervin (Eds.), Handbook of Personality (3rd Ed.), pp. 568-580. New York: Guilford.

Garson, G. D. (2009). Structural equation modeling. Statnotes: Topics in multivariate analysis.

Grandey, A.A. (2000). Emotion regulation in the workplace: A new way to conceptualize emotional labor. Journal of Occupational Health Psychology, 5, 95-110.

Harris, K. J., Harvey, P., \& Kacmar, K. M. (2009). Do social stressors impact everyone equally? An examination of the moderating impact of core self-evaluations. Journal of Business \& Psychology, 24(2), 153-153-164.

Hicks, L. E. (1970). Some properties of ipsative, normative, and forced-choice normative measures. Psychological Bulletin, 74, 167-184.

Holman, D., Chissick, C., \& Totterdell, P. (2002). The effects of performance monitoring on emotional labor and well-being in call centers. Motivation and Emotion, 26, 57-81.

Holtom, B.C., Mitchell, T.R., Lee, T.W., \& Inderrieden, E.J. (2005). Shocks as causes of turnover: what they are and how organizations can manage them. Human Resource Management, 44(3), 337-352.

Hough, L. M., \& Schneider, R. J. (1996). Personality traits, taxonomies, and applications in organizations. In K. R. Murphy (Ed.), Individual differences and behavior in organizations (pp. 31-88). San Francisco: Jossey-Bass.

Jöreskog, K. G., \& Sörbom, D. (2006). LISREL 8.80 for Windows. Computer Software]. Lincolnwood, IL: Scientific Software International, Inc.

Judge, T. A., \& Larsen, R. J. (2001). Dispositional source of job satisfaction: A review and theoretical extension. Organizational Behavior and Human Decision Processes, 86, 6798.

Kenny, D. A., Kashy, D. A., \& Bolger, N. (1998). Data analysis in social psychology. In D. Gilbert, S. Fiske, \& G. Lindzey (Eds.), The handbook of social psychology. 1(4), 233265.

LeBreton, J.M., Binning, J.F., Adorno, A.J., \& Melcher, K.M. (2004). Importance of personality and job-specific affect for predicting job attitudes and withdrawal behavior. Organizational Research Methods, 7, 300-325.

Lee, T.W., \& Mitchell, T.R., (1994). An alternative approach: the unfolding model of voluntary employee turnover. The Academy of Management Review. 19(1), 51-89. 
Little, T. D., Bovaird, J. A., \& Widaman, K. F. (2006). On the merits of orthogonalizing powered and product terms: Implications for modeling interactions among latent variables. Structural Equation Modeling, 13(4), 497-519.

MacCallum, R.C., Wegener, D.T., Uchino, B.N., Fabrigar, L.R. (1993). The problem of equivalent models in applicants of covariance structure analysis. Psychological Bulletin, 114, 185-199.

Morrell, K., Loan-Clarke, J., \& Wilkinson, A. (2004). The Role of Shocks in Employee Turnover. British Journal of Management, 15, 335-349.

Morris, J. A., \& Feldman, D. C. (1996). The dimensions, antecedents, and consequences of emotional labor. Academy of Management Review, 21, 986-1010.

Nunnally, J.C. (1967). Psychometric Theory. McGraw-Hill: New York.

Raykov, T., \& Marcoulides, G.A. (2001). Can there be infinitely many models equivalent to a give covariance structure model? Structural Equation Modeling, 8, 142-149.

Ringler, J.M., Binning, J.F., Schneider, K.T. (2007; April). Trait affect interactions with hassles and uplifts on work withdrawal. Paper presented at the Annual Conference of the Society for Industrial and Organizational Psychology, New York, NY.

Robinson, M.D., \& Clore, G.L. (2002). Episodic and semantic knowledge in emotional selfreport: Evidence for two judgment processes. Journal of Personality and Social Psychology, 83, 198-215.

Schrieber, J.B., Stage, F.K., King, J., Nora, A., \& Barlow, E.A. (2006). Reporting structural equation modeling and confirmatory factor analysis results: A review. The Journal of Education Research, 99(6), 323-337.

Tabachnick, B. G., \& Fidell, L. S. (2007). Using Multivariate Statistics (5 ${ }^{\text {th }}$ Ed). New York: Pearson Education, Inc.

Tanaka, J. S. Multifaceted conceptions of fit in structural equations models. In: Bollen, K. A. and Long, J. S. (Eds.) Testing structural equation models, London: Sage, 1993, pp. 10-39.

Tett, R. P., \& Burnett, D. D. (2003). A personality trait-based interactionist model of job performance. Journal of Applied Psychology, 88(3), 500.

Tinsley, H. E. A. (2000). The congruence myth: An analysis of the efficacy of the person environment fit models. Journal of Vocational Behavior, 56(2), 147-179.

Tziner, A. \& Birati, A. (1996). Assessing employee turnover costs: A revised approach. Human Resources Management Review. 6(2), 113-122.

Watson, D., \& Clark, L.A. (1992). Affects separable and inseparable: On the hierarchical arrangement of the negative affects. Journal of Personality and Social Psychology, 62, 489-505. 
Watson, D., Clark, L.A., \& Harkness, A.R. (1994). Structures of personality and their relevance to psychopathology. Journal of Abnormal Psychology, 103, 18-31.

Watson, D., \& Clark, L. A. (1997). Extraversion and its positive emotional core. In R. Hogan, J. Johnson, \& S. Briggs (Eds.), Handbook of personality psychology (pp. 767-793). San Diego, CA: Academic Press.

Watson, D., Wiese, D., Vaidya, J, \& Tellegen, A. (1999). The two general activation systems of affect: Structural findings, evolutionary considerations, and psychobiological evidence. Journal of Personality and Social Psychology, 76, 820-838.

Weiss, H. M. (2002). Deconstructing job satisfaction: Separating evaluations, beliefs and affective experiences. Human Resource Management Review, 12(2), 173-194.

Weiss, H.M., \& Cropanzano, R. (1996). Affective events theory: A theoretical discussion of the structure causes and consequences of affective experiences at work. Research in Organizational Behavior, 18, 1-74.

Zimmerman, R. D. (2008). Understanding the impact of personality traits on individuals' turnover decisions: A meta-analytic path model. Personnel Psychology, 61(2), 309-348.

Zuckerman, M., Kuhlman, D.M., Joireman, J., \& Teta, P. (1993). A comparison of three structural models for personality: The big three, the big five, and the alternative five. Journal of Personality and Social Psychology, 65, 757-768. 